\title{
Improving crop disease resistance: lessons from research on Arabidopsis and tomato
}

\author{
Sophie J. M. Piquerez ${ }^{\dagger}$, Sarah E. Harvey ${ }^{\dagger}$, Jim L. Beynon* and Vardis Ntoukakis*
}

School of Life Sciences, University of Warwick, Coventry, UK

\section{Edited by:}

Ksenia V. Krasileva, University of California Davis, USA

Reviewed by:

Felix Mauch, University of Fribourg, Switzerland

Florian Jupe, The Sainsbury

Laboratory, UK

\section{${ }^{*}$ Correspondence:}

Jim L. Beynon and Vardis Ntoukakis, School of Life Sciences, University of Warwick, Gibbet Hill Road, Coventry CV4 7AL, UK

e-mail: jim.beynon@warwick.ac.uk; v.ntoukakis@warwick.ac.uk

${ }^{\dagger}$ Sophie J. M. Piquerez and Sarah E. Harvey have contributed equally to this work.

\begin{abstract}
One of the great challenges for food security in the 21 st century is to improve yield stability through the development of disease-resistant crops. Crop research is often hindered by the lack of molecular tools, growth logistics, generation time and detailed genetic annotations, hence the power of model plant species. Our knowledge of plant immunity today has been largely shaped by the use of models, specifically through the use of mutants. We examine the importance of Arabidopsis and tomato as models in the study of plant immunity and how they help us in revealing a detailed and deep understanding of the various layers contributing to the immune system. Here we describe examples of how knowledge from models can be transferred to economically important crops resulting in new tools to enable and accelerate classical plant breeding. We will also discuss how models, and specifically transcriptomics and effectoromics approaches, have contributed to the identification of core components of the defense response which will be key to future engineering of durable and sustainable disease resistance in plants.
\end{abstract}

Keywords: Arabidopsis, tomato, model, crop engineering, disease resistance, food security

\section{INTRODUCTION}

Plants are exposed to a wide-range of pests and pathogens, encompassing bacteria, fungi, oomycetes, viruses, nematodes, and insects but only in specific interactions does this result in disease. However, an average of $26 \%$ of the worldwide crop production is lost each year due to pre-harvest pests and pathogens (Oerke, 2006). Increasing human populations, loss of agricultural land due to climate change, erosion and lack of water require that we reduce production losses such as those caused by pathogens as much as possible (Bebber et al., 2013). The four major staples produced worldwide, rice (which feeds more than half the world population), wheat, maize and banana are constantly threatened by damaging emerging infectious diseases in both developing and developed countries (Fisher et al., 2012). Serious biological threats to food security include Puccinia graminis f. sp. tritici (the causal agent of wheat stem rust), a highly virulent strain of which (Ug99) emerged in 1998 in East Africa. This strain overcomes the resistance genes used in crops to combat stem rust, and has spread dramatically on the African continent and to Asia (Ayliffe et al., 2008). Another serious threat, the oomycete pathogen Phytophthora infestans is the causative agent of late blight of potato and tomato, resulting in the deaths of 1.25 million people during the Irish potato famine of 1845 and remaining a contemporary problem (Haverkort et al., 2008; Pennisi, 2010). In addition, Black Sigatoka caused by Mycosphaerella fijiensis and Panama disease caused by Fusarium oxysporum f. sp. cubensis threaten banana fields, a major staple food in developing countries (Butler, 2013) and soybean production worldwide is constrained by cyst nematodes and rust caused by the fungus Phakopsora pachyrhizi (Carmona etal., 2005; Pivonia et al., 2005). Compounded by poleward movement of pathogens due to climate change (Bebber et al., 2013), there are numerous examples of emerging disease that may develop into uncontrollable epidemics and jeopardize food security if countermeasures are not deployed.

In the absence of genetic resistance in crops, food production heavily relies on chemical control of pathogens. Despite their effectiveness, copper based chemicals have detrimental environmental consequences, building up in the soil and appearing in water leaching from fields creating risks to the wider environment. Modern synthetic chemicals usually have reduced environmental toxicity, however, they are expensive and only available to advanced agricultural production systems. As with antibiotics, discovery of new chemistry is difficult and extensive use of current agents may result in selection of pathogen strains tolerant to pesticides (Marco and Stall, 1983; Childers et al., 2014; Hahn, 2014). Reducing the dependence of food production on chemical control is a key goal of plant pathology research. Hence, to ensure sustainable food security, we need to engineer long-lasting and broad-spectrum disease resistance in crops. One of the major goals of plant research in the 21st century is to increase our understanding of the plant immune system and unravel how this is manipulated by pathogens, in order to engineer transgenic crops with both durable resistance against pathogens and increased yields (Dangl et al., 2013).

In this review we discuss how advances in model systems have been instrumental in the emergence of new ways to manipulate the host defense responses (Table 1). Work from Arabidopsis and tomato has allowed us to build comprehensive models of the plant immune system and elucidate the mechanism used by pathogens to suppress its effectiveness (Jones and Dangl, 2006). We have now reached the stage where it is possible to propose holistic ways to 
Table 1 | Well-described examples of transfer of research from models to crops.

\begin{tabular}{|c|c|c|c|}
\hline & Pathogen & Model plants & Application in crops \\
\hline \multirow[t]{2}{*}{$N L R$ genes } & Broad range of pathogens & $\begin{array}{l}R \text { gene discovery, cloning and } \\
\text { understanding }\end{array}$ & $\begin{array}{l}\text { More efficient } R \text { gene cloning and intra- and } \\
\text { interspecies transfer }\end{array}$ \\
\hline & & $\begin{array}{l}\text { Arabidopsis RPS4/RRS1 (Narusaka } \\
\text { etal., 2009) }\end{array}$ & $\begin{array}{l}\text { Transfer of RPS4/RRS1 to Brassicas, cucumber } \\
\text { (Narusaka etal., 2013a) }\end{array}$ \\
\hline \multirow[t]{2}{*}{$\begin{array}{l}\text { Transfer of PRRs } \\
\text { across species }\end{array}$} & $\begin{array}{l}\text { Broad range of phytopathogenic } \\
\text { bacteria }\end{array}$ & $\begin{array}{l}\text { Arabidopsis EFR tested in tomato } \\
\text { (Lacombe et al., 2010) }\end{array}$ & $\begin{array}{l}\text { Transfer of EFR into crops such as potato, lettuce, } \\
\text { apple, citrus }^{a}\end{array}$ \\
\hline & & $\begin{array}{l}\text { Tomato Ve1 tested in Arabidopsis } \\
\text { (Fradin et al., 2011) }\end{array}$ & \\
\hline \multirow[t]{3}{*}{$\begin{array}{l}\text { Host-induced gene } \\
\text { silencing (HIGS) }\end{array}$} & $\begin{array}{l}\text { Crown gall; Agrobacterium } \\
\text { tumefaciens }\end{array}$ & $\begin{array}{l}\text { Proof of concept: silencing of iaaM and } \\
\text { ipt in Arabidopsis and tomato (Escobar } \\
\text { etal., 2001) }\end{array}$ & $\begin{array}{l}\text { Silencing of iaaM, ipt, Pv010 in walnut roots } \\
\text { Malawage etal., 2013) }\end{array}$ \\
\hline & $\begin{array}{l}\text { Root knot nematodes; } \\
\text { Meloidogyne spp. }\end{array}$ & $\begin{array}{l}\text { Silencing of Arabidopsis 16D10 (Huang } \\
\text { etal., 2006) }\end{array}$ & Silencing of $16 D 10$ in grape (Yang et al., 2013b) \\
\hline & $\begin{array}{l}\text { Fusarium head blight; Fusarium } \\
\text { graminearum }\end{array}$ & $\begin{array}{l}\text { Silencing of Arabidopsis CYP51 (Koch } \\
\text { etal., 2013) }\end{array}$ & Silencing of CYP51 in barley (Koch et al., 2013) \\
\hline Non-host resistance & $\begin{array}{l}\text { Asian soybean rust; Phakopsora } \\
\text { pachyrhizi }\end{array}$ & $\begin{array}{l}\text { Identification of BRT1 as a component } \\
\text { of non-host resistance (Langenbach } \\
\text { etal., 2013) }\end{array}$ & $\begin{array}{l}\text { BRT1 transferred into soybean (Conrath et al., } \\
\text { 2013) }\end{array}$ \\
\hline $\begin{array}{l}\text { Transgenerational } \\
\text { systemic acquired } \\
\text { resistance (SAR) }\end{array}$ & $\begin{array}{l}\text { Pseudomonas syringae, } \\
\text { Hyaloperonospora arabidopsidis } \\
\text { and Rhynchosporium commune }\end{array}$ & $\begin{array}{l}\text { Heritable resistance in Arabidopsis due } \\
\text { to pathogen (Luna et al., 2012) or } \\
\text { chemical treatment (Slaughter et al., } \\
\text { 2012) }\end{array}$ & $\begin{array}{l}\text { Heritable resistance in barley conferred upon } \\
\text { pathogen and chemical treatment Walters and } \\
\text { Paterson, 2012); heritable resistance to wheat } \\
\text { streak mosaic virus in wheat } \\
\text { (Seifers et al., 2014) }\end{array}$ \\
\hline
\end{tabular}

a http://2blades.org

alter crop genetics with the aim of engineering low cost durable resistance mechanisms in crop plants.

\section{Arabidopsis AND TOMATO AS MODELS IN PLANT-PATHOGEN INTERACTIONS}

Tomato (Solanum lycopersicum) belongs to the Solanaceae family, which encompasses many important crops such as potato, pepper, and eggplant. It is the second most important vegetable crop worldwide, having reached a production of more than 160 million tones FAOSTAT (2012). Historically, tomato was a reference species and a model not only for fleshy, berry-type fruit development and ripening but also for plant-pathogen interactions (Giovannoni, 2001, 2004; Takahashi et al., 2005; Arie et al., 2007). Tomato plants are infected by a plethora of diseases (Jones et al., 1991) and given that tomato was easily transformable, had transposons and a defined pathogen genetics with Cladosporium fulvum, it stood as an excellent model of choice to unravel disease resistance. Indeed major breakthroughs on the identification of genes involved in disease resistance (Figure 1, Martin et al., 1993; Jones et al., 1994; Salmeron et al., 1996) and the understanding of resistance complex formation and activation have been described in tomato (recently reviewed in Ntoukakis et al., 2014; decisive papers including Tang et al., 1996; Kim et al., 2002; Xing et al., 2007; Mucyn et al., 2009; Ntoukakis et al., 2009, 2013). Recently, the tomato genome was sequenced (Tomato Genome Consortium, 2012), further strengthening its position as a model for plant-pathogen interactions.

Since the 1980s, Arabidopsis has been extensively studied as a model within the dicotyledonous plants; milestones are described in Figure 1. Somerville and Koornneef (2002) reported that by the early 2000s, over 2500 papers a year were being published describing research carried out on Arabidopsis and in 2013 this figure was almost 5000 (PubMed searches matching "Arabidopsis" or "thaliana"), demonstrating the power of focusing the effort of the scientific community on this small flowering weed. The impressive amount of tools and resources made available to the plant research community has contributed to many major breakthroughs in our understanding of how a plant functions, the most striking example being the dissection of floral morphogenesis (Koornneef and Meinke, 2010). From the early 


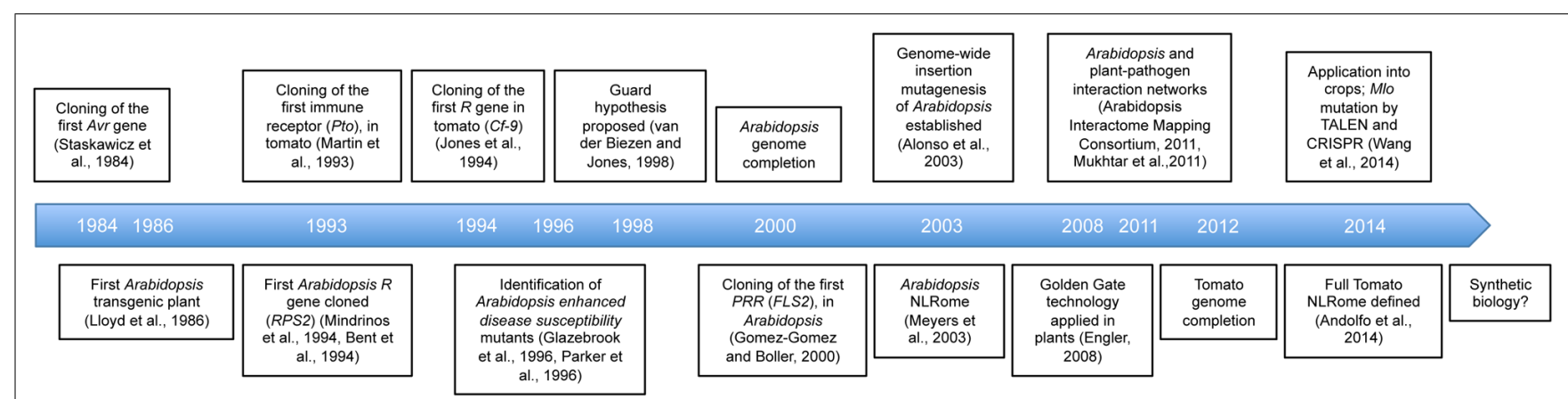

FIGURE 1 | Milestones associated with the use of Arabidopsis and tomato as research models.

days of research on Arabidopsis, its potential as a model for plant-pathogen interactions was recognized (Sijmons et al., 1991; Mauch-Mani and Slusarenko, 1993; Crute etal., 1994; Buell, 1998). Several natural pathogens with wide host ranges can infect Arabidopsis, including Xanthomonas campestris pv. campestris, Pseudomonas viridiflava, and Pseudomonas syringae (Tsuji, 1992; Jakob et al., 2002). However, others such as Hyaloperonospora arabidopsidis only grow and reproduce on Arabidopsis, hence this pathosystem can be used to study host-pathogen coevolution (Holub and Beynon, 1997; Holub, 2007, 2008; Coates and Beynon, 2010). Another interesting pathogen of Arabidopsis is the white rust causal agent Albugo (Holub et al., 1995; Thines et al., 2009) which can also cause major diseases in Brassica crops (Pound and Williams, 1963; Verma etal., 1975; Liu etal., 1989) and can suppress several broad-spectrum disease resistances (Cooper et al., 2008). Surprisingly, one of the most extensively studied pathogens of Arabidopsis is the bacterium Pseudomonas syringae pv. tomato DC3000, even though never isolated from Arabidopsis itself in the wild, it can perfectly proliferate and cause disease symptoms (Whalen et al., 1991; Xin and He, 2013).

\section{BREEDING FOR RESISTANCE: STRATEGIES DEPLOYED SO FAR}

Resistant crop varieties have been selected by traditional breeding for more than 100 years, the first mention of wheat disease resistance breeding programs dating from Biffen (1905). However, at the time, traditional breeding programs were identifying and introgressing resistance sources in crops by crossing and selecting for traits well before understanding the mechanism of action of resistance $(R)$ genes (refer to Box $\mathbf{1}$ for definition of core concepts of plant immunity). Our initial understanding of plant disease resistance was shaped by the work of Flor (1955) over half a century ago who genetically defined the 'gene-for-gene' concept as requiring an avirulence $(A v r)$ gene in the pathogen and an $R$ gene in the host plant. While the first Avr gene (AvrA) was cloned 30 years ago (Staskawicz et al., 1984), the identification and cloning of single resistance loci of $R$ genes took much longer. The first gene contributing to resistance, Pto, came from tomato and conferred resistance to Pseudomonas syringae strains carrying AvrPto and AvrPtoB (Martin et al., 1993; Scofield et al., 1996; Tang et al., 1996; Kim et al., 2002). Concurrently, the first 'true'

\section{BOX 1 | Today's core concepts of plant immunity.}

Pathogen-associated molecular patterns (PAMPs) are chemically conserved structures amongst many organisms, such as flagellin or chitin.

PRR-triggered immunity (PTI) relies on the activation of membrane bound pattern-recognition receptors (PRRs) upon recognition of PAMPs. PRRs are often receptor-like kinases (RLKs) themselves or associated with RLKs and activation leads to induction of signaling cascades, transcriptional reprograming and a complex defense output including the production of anti-microbial compounds. The most studied PRR is the receptor for bacterial flagellin; FLS2. PTI is considered as a basal source of resistance because it is triggered in both susceptible and resistant interactions.

Effector/avirulence (Avr) genes (often referred to as effectors) encode molecules delivered from the pathogen to the host plant. Generally effectors manipulate host immunity, thus preventing PTI from halting successful growth and reproduction of the pathogen. Resistance $(\boldsymbol{R})$ genes encode cytoplasmically located resistance proteins $(R)$, also called nucleotide-binding site leucine-rich repeat (NLR) proteins.

Effector-triggered immunity (ETI) or $R$ gene mediated resistance relies on the activation of resistance proteins in the presence of the corresponding Avr protein. This very specific R-Avr interaction is known as gene-for-gene resistance (Flor, 1971; Dangl and Jones, 2001) and occurs in some genotypes within a plant species. ETI often results in programmed cell death termed the hypersensitive response. Two well-described examples of R-Avr gene pairs come from research on Arabidopsis and tomato; the effector protein AvrRpm1 is recognized by Rpm1 via another host protein RIN4, AvrPto is recognized by Prf via Pto (Mackey et al., 2002; Mucyn et al., 2006).

(nucleotide-binding site leucine-rich repeat; NLR) $R$ genes were identified in Arabidopsis (Bent et al., 1994; Mindrinos et al., 1994) and soon after the interacting $R$ gene of Pto (Prf) was identified in tomato (Salmeron et al., 1996). Subsequently many other $R$ genes were quickly identified, mostly from Arabidopsis and tomato and bestowing resistance to a variety of pathogens including viruses (Kohm et al., 1993; Whitham et al., 1994), bacteria (Bent etal., 1994; Mindrinos etal., 1994; Grant etal., 1995), fungi (Jones etal., 1994; Dixon etal., 1996), and oomycete pathogens (Botella et al., 1998). These major discoveries instigated the basis of the plant-microbe interaction field as we know it today. 
In 2003, the characterization of the Arabidopsis resistance gene complement (NLRome) consisting of 149 NLRs contributed significantly to our understanding of $R$ gene structures, both through their conservation and diversity and facilitated targeted approaches to indict specific genes in resistance (Meyers et al., 2003). Following this major development in Arabidopsis, which proved to be an extremely useful tool, NLRomes were investigated in more complex plant species. Thanks to the recent release of the tomato genome, a comprehensive tomato NLRome comprising 355 NLRs is now available (Tomato Genome Consortium, 2012; Andolfo et al., 2013, 2014; Jupe et al., 2013a). The availability of such NLRomes can really speed up the mapping and cloning of new resistance loci in segregating populations by integrating genetics and genomics; once a rough mapping position has been identified, one can pinpoint the locus to a few candidate NLRs.

Historically breeders have been selecting for more resistant crops by classically identifying new resistance sources and introgressing them into economically important crops. Transgenic approaches, however, are estimated to save 15 years on classical breeding for resistance (Haverkort et al., 2008), so it is essential that a new generation of modified plants comes to light. Since 1993, researchers have used genetic engineering to introduce genes of interest to existing high-yielding varieties without undesired pleiotropic effects. Up to now a few transgenic $R$ genes have been transferred and tested into crops, whether coming from the same species or from wild relative species (reviewed in Dangl et al., 2013).

Deploying single $R$ genes into the field has proven to be a rather transient solution to disease, for instance the Brassica Rlm1mediated resistance was defeated within 5 years of deployment (Sprague et al., 2006). In order to tackle field resistance failures, several options are being explored. Previously, one strategy used to reduce the selective pressure on a pathogen to overcome resistance in the field is the use of multiline varieties. These contain multiple seed lines differing in their gene-specific resistances and therefore reduce the disease inoculum compared to a susceptible monoculture (Johnson and Allen, 1975). Another strategy, called $R$ gene stacking or pyramiding, relies on the deployment of multiple NLRs at once in a single cultivar. Combining several $R$ genes ensures that if the pathogen mutates to overcome one $R$ gene, other resistance sources will continue to be effective. Such an approach has been particularly successful in potato cultivars (Kim et al., 2012; Jo et al., 2014). The critical need for new sources of resistance led researchers to look for resistance genes from wild relatives of crop species. Rpi-vnt1.1 was transferred from Solanum venturii (wild potato) into Solanum tuberosum (edible potato) with success as tested in field trials for three consecutive years (Jones et al., 2014). $R$ genes have been transferred between unrelated species with a relatively good success rate, proving to be a valuable tool to achieve durable disease resistance (Zhao et al., 2004, 2005; Yang et al., 2013a).

The obvious question is now how to extend the life of $R$ genes, and for this we need to utilize models. The conservation of the signaling occurring downstream of NLRs across plant lineages has become evident (Maekawa etal., 2012), which is why model plants are required for detailed understanding of the mechanism underlying $R$ gene activation in order to extend the life of single $R$ genes. For example, the tomato $V e 1$ gene was transferred successfully to Arabidopsis in order to dissect the signaling component involved in Vel-medited resistance (Fradin et al., 2009, 2011). Similarly, despite having first identified Rpm1/Rpg1mediated resistance in soybean (Staskawicz et al., 1984; Innes et al., 1993; Ashfield et al., 1995, 1998), it was further and largely characterized in Arabidopsis. This led to the identification of RIN4, a major negative regulator of plant defense and a target of several effector proteins (Mackey et al., 2002, 2003; Axtell and Staskawicz, 2003). Accessory proteins, such as RIN4, act as a bridge between $\mathrm{R}$ proteins and effectors, either as a direct virulence target of the effector (Van Der Biezen and Jones, 1998) or as a structural mimic of one [decoy (van der Hoorn and Kamoun, 2008) or bait model (Collier and Moffett, 2009)]. Subsequently, knowledge acquired in Arabidopsis is now being transferred back to soybean in an effort to understand the role of accessory proteins in $R$ gene-mediated resistance in crop plants (Selote and Kachroo, 2010).

In some cases, NLRs function in pairs to mediate recognition (Eitas and Dangl, 2010) and $R$ gene dimerization has been described in both model plants and crop species (Mestre and Baulcombe, 2006; Bernoux et al., 2011; Maekawa et al., 2011). For example, the role of oligomerization in effector recognition has extensively been described for the Pto/Prf interaction (Gutierrez et al., 2010; Ntoukakis et al., 2013). The use of model plants appears crucial in the discovery of the resistance complexes, and raises the importance of the transfer of the partners of the $R$ genes into crops in order to recreate a functional module. For example, one $R$ gene pair in Arabidopsis is the RPS4/RRS1 pair which forms a complex in vivo that is able to recognize at least two bacterial effectors and a fungal effector (Birker et al., 2009; Narusaka et al., 2009; Williams et al., 2014). This $R$ gene cooperation can provide disease resistance with extended spectrum as it is efficient against different classes of pathogens and has been deployed in several crops (Narusaka et al., 2013a,b, 2014; Table 1).

One way to tackle the durability issue of $R$ genes is to study $R$ gene evolution in the context of the whole resistance complex. Well-studied resistance mechanisms in tomato allowed this issue to be elegantly addressed by Grzeskowiak et al. (2014) for the Pto/Fen/Prf resistance complex. Pto homologs and Prfare colocalized genomically, suggesting that they evolved concurrently. As described earlier, $\mathrm{R}$ protein activation relies on a change of conformation upon perception of an effector or an effector-modified plant protein and the proper oligomerization and interaction with other proteins (Bonardi et al., 2012). Recent studies of artificial evolution of the potato resistance gene $R x$ (that confers resistance to potato virus $\mathrm{X}$ ) showed that by mutating specific residues/regions, it is possible to manipulate the defense activation output and generate resistance to other pathogens, in this case to poplar mosaic virus (Farnham and Baulcombe, 2006; Harris et al., 2013).

\section{THE POWER OF MODELS: CHARACTERIZATION OF MUTANTS}

Arabidopsis mutants have been indispensible in elucidating gene regulatory mechanisms and are a stellar example of how using a model system such as Arabidopsis aids understanding of how 
crop plants respond to biotic and abiotic stress. The wellannotated genome and the availability of mutants generated both by EMS mutagenesis (Rédei and Koncz, 1992; Greene et al., 2003) and T-DNA insertion (Alonso etal., 2003) allows rapid characterization of gene function in Arabidopsis using both forward and reverse genetic approaches. In the early days of molecular plant pathology, characterization of Arabidopsis mutants such as non-expresser of PR genes (npr1; Cao et al., 1994) and several enhanced disease susceptibility (eds) mutants (Glazebrook et al., 1996; Parker et al., 1996) allowed dissection of the genetic basis of the plant immune response for the first time. More recently, mutant screens also identified flagellin sensing 2 (fls2), the most studied pattern recognition receptor (PRR) to date (GómezGómez and Boller, 2000) but also one of the major regulator of PRR activation BAK1 (brassinosteroid insensitive 1-associated protein kinase), even though originally identified as a suppressor of brassinosteroid signaling (Li et al., 2002; Chinchilla et al., 2007; Heese et al., 2007); furthering our understanding of early signaling during PRR-triggered immunity (PTI; Box 1).

Model plants have enabled our understanding of the interplay between immunity and development (Tian et al., 2003; Heidel et al., 2004; Bolton, 2009; Göhre et al., 2012; Lozano-Durán et al., 2013). Auto-activated or constitutively expressed NLRs such as SNC1 lead to dwarf phenotypes (Zhu et al., 2010), which emphasize the importance of fine-tuning of $R$ gene expression regulation. Similarly the MAP Kinase 4 (mpk4) mutant that exhibits constitutive activation of systemic acquired resistance, displays a dwarf phenotype (Petersen et al., 2000).

The regulation of stress responses and hormone signaling has also been elucidated using Arabidopsis mutants (Koornneef etal., 1984; Cao etal., 1994; Finkelstein, 1994; Xie et al., 1998). Now we have been able to characterize the antagonism in hormone signaling between salicylic acid (SA) and jasmonic acid (JA), which allows plants to tailor their defense depending on the pathogen (Glazebrook, 2005; Robert-Seilaniantz et al., 2011) and is open to manipulation by pathogens to aid colonization (Marumo et al., 1982; Valls et al., 2006; El Oirdi et al., 2011). In addition to characterization of hormone signaling pathways, we are starting to unravel their regulation. For example the topless developmental mutant was identified in Arabidopsis following EMS mutagenesis by Long etal. (2002). It has since been shown in Arabidopsis that in addition to regulation of auxin signaling (Osmont and Hardtke, 2008), TOPLESS (TPL) negatively regulates JA-responsive genes (Pauwels et al., 2010) and has been implicated in negative regulation of SA signaling (Arabidopsis Interactome Mapping Consortium, 2011). Recently, TPL and multiple family members have been identified in many higher plants and their localization and interaction with repressors in auxin signaling shown in tomato (Hao et al., 2014). Together with our knowledge from Arabidopsis, this gives potential for manipulation of hormonal defense in crop species.

The detailed analysis of mutants in Arabidopsis has resulted in a detailed understanding of stress signaling which is being transferred to crops. Among many other examples described is the SnRK2 family of protein kinases which play a role in abscisic acid signaling and were identified and characterized in Arabidopsis over a decade ago (Yoshida et al., 2002; Hrabak et al., 2003). This family is now being characterized in crop species including maize (Huai et al., 2008), sorghum (Li et al., 2010), and rice (Xu et al., 2013). Another example is the NAC family of transcription factors, which play a role in response to biotic and abiotic stress (Wang et al., 2009; Nakashima et al., 2012). Recently these NAC transcription factors have been characterized in potato, aided by the previous description of their functionality in Arabidopsis (Tian et al., 2003; Singh et al., 2013) and their manipulation by effectors from Phytophthora infestans has been shown (McLellan et al., 2013).

\section{PATTERN RECOGNITION: DEFENSE AGAINST CONSERVED MICROBIAL COMPONENTS}

Understanding of the immune response gained from models and particularly the scrutiny of mutants has enabled us to characterize the receptors and signaling associated with plant immunity, particularly differentiating between PTI and effector-triggered immunity (ETI; Box 1). Using this knowledge, one way to achieve broader spectrum resistance is to make use of PRRs. Lacombe et al. (2010) elegantly showed that EF-Tu receptor (EFR), a PRR gene restricted to the Brassicaceae genus, confers increased resistance to various bacterial pathogens when expressed in Solanaceae. Given that EFR confers broad-spectrum resistance to a variety of bacterial pathogens, it is being currently tested for its action in potato, lettuce, citrus and apple ${ }^{1}$. This is the first example of transferring a $P R R$ between genera and suggests that the downstream PAMP-induced signaling cascade is conserved between species, paving the way to further utilize this source of resistance. Similarly, $X a 21$, a $P R R$ restricted to rice, was transferred to orange, tomato and banana (Ronald et al., 1992; Afroz et al., 2010; Mendes et al., 2010; Tripathi et al., 2014) and DORN1 (does not respond to nucleotides 1, also called LecRK-I.9), the extracellular ATP (eATP) receptor, was transferred into potato (Bouwmeester et al., 2014). Even though effectors can target PRRs and suppress PTI outputs (Göhre et al., 2008; Gimenez-Ibanez et al., 2009; Zhang et al., 2010), PRRs still stand as a potent additional source of resistance for disease control. Similar to the identification of NLRomes, efforts have been made to identify PRRomes (Fritz-Laylin et al., 2005; Tang et al., 2010; Andolfo et al., 2013). Plant genomes encode hundreds of receptor-like proteins and receptor-like kinases that may be potential PRRs involved in disease resistance. A future promising approach to improve disease resistance could be to combine known PRRs and NLR $R$ genes in a same cultivar that would confer simultaneously increased resistance to a widerange of pathogens and strong resistance to specific pathogenic strains.

\section{NON-HOST RESISTANCE: A SOURCE OF DURABLE RESISTANCE?}

Non-host resistance (NHR) arises when an entire plant species is resistant to a pathogen (Heath, 1981; Singh et al., 2013) and since it is much more durable than $R$ gene mediated resistance, potentially, it could be an exciting new means of crop improvement. Arabidopsis displays NHR to several commercially important pathogens such as the potato blight pathogen Phytophthora infestans and the causal agent of Asian soybean rust

${ }^{1}$ http://2blades.org 
(ASR), Phakopsora pachyrhizi (Huitema et al., 2003; Loehrer et al., 2008). It has therefore been possible to use a series of Arabidopsis mutants to identify components of NHR. These mutants, designated the penetration (pen) mutants, allow the penetration of fungal pathogens to which Arabidopsis is a non-host (Collins et al., 2003; Assaad et al., 2004). They have allowed important components of NHR to be unraveled such as PEN1 which is a membrane-anchored syntaxin involved with vesicle trafficking to the cell membrane and PEN2 and PEN3 which are thought to work together in producing and delivering antifungal compounds to the apoplast upon attempted infection (Collins et al., 2003; Lipka et al., 2005; Stein et al., 2006; Loehrer et al., 2008). Transcriptional profiling of pen mutants has allowed the identification of postinvasion induced NHR genes (PINGs) such as bright trichomes 1 (BRT1; Langenbach et al., 2013). Critically, it has recently been shown that transferring BRT1 from Arabidopsis to soybean results in reduction in disease symptoms of ASR (patent by Conrath et al., 2013).

Multiple components contribute to NHR but the exact mechanisms are not yet fully understood. NHR may partially be mediated by $R$ genes, as when effectors are expressed ectopically in a non-host plant some can trigger an ETI like resistance response (Kobayashi et al., 1989). Two Arabidopsis $R$ genes seem to play a role against NHR to the Brassica fungal pathogen Leptosphaeria maculans (Staal etal., 2006). Additionally, NHR in Arabidopsis against powdery mildew involves cell wall appositions and production of antimicrobial compounds. A proposed model by Schulze-Lefert and Panstruga (2011) suggests that the relative contribution of PTI (as opposed to recognition by $\mathrm{R}$ proteins) increases with evolutionary distance from the host plant. It is therefore thought that through studying NHR we may be able to find and engineer durable resistance mechanisms independently of $R$ protein recognition.

\section{OMICS' APPROACHES EFFECTORS, EFFECTOROMICS, AND PATHOGENOMICS}

Pathogens deploy an arsenal of toxins and effector proteins, which play an important role in manipulation and suppression of plant defenses during disease (Jones and Dangl, 2006). Pathogen effector repertoires can vary in size; Pseudomonas syringae has a typical core of 10-40 effectors (Guttman et al., 2002; Petnicki-Ocwieja et al., 2002; Baltrus et al., 2011; O’Brien et al., 2011; Lindeberg et al., 2012), whereas the oomycete pathogen Phytophthora infestans has around 500 effectors (Haas et al., 2009; Bozkurt et al., 2012). Yeast-two-hybrid ( $\mathrm{Y} 2 \mathrm{H})$ systems have been instrumental for the pairing of resistance proteins and effector proteins. Following the identification of Pto in tomato (Martin et al., 1993), the bacterial effectors AvrPto and AvrPtoB were identified as its interacting partners using a $\mathrm{Y} 2 \mathrm{H}$ system (Scofield et al., 1996; Kim etal., 2002). Despite the early success of the Y2H system, subsequent experiments trying to pair $\mathrm{R}$ proteins and effectors had limited success. In hindsight, this is because direct interaction between $\mathrm{R}$ proteins and effectors appears to be the exception (Jia et al., 2000; Deslandes et al., 2003; Dodds et al., 2006; Krasileva et al., 2010; Cesari et al., 2013), often relying on accessory proteins that can bridge the two. More recent -omics studies support the idea that direct interaction is the exception and indirect interaction of the effectors with the $\mathrm{R}$ proteins is commonly the case (Mukhtar et al., 2011). However, effectors have still assisted us in selecting $R$ genes for breeding; this was elegantly shown using the AvrBs2 effector which is highly conserved in Xanthomonas species. Transfer of the corresponding resistance gene (Bs2) from pepper into tomato was successful at providing resistance to Xanthomonas perforans (Horvath et al., 2012).

Effectors can also be used as a powerful tool to dissect the plant immune response by identifying key components or modifications required for activation of immunity. A comprehensive roadmap for effector discovery and functional analysis has been described before (Alfano, 2009) with the eventual aim of engineering plants with durable disease resistance. Basic components of the roadmap are the identification of host interacting proteins, mode of function, and localization of the effector that can be valuable tools in our efforts to unravel a plant defense mechanisms. For instance, the characterization of the effector HopU1 unraveled the role of the RNA-binding protein GRP7 in immunity (Nicaise et al., 2013) and more recently Macho et al. (2014) benefited from the functional characterization the effector HopAO1to dissect the role of tyrosine phosphorylation in PTI.

Using model systems has facilitated $\mathrm{Y} 2 \mathrm{H}$ genome-wide studies which have resulted in the identification of Arabidopsis protein 'hubs' that are converged on by independently evolved effectors from multiple species (Mukhtar et al., 2011; Weßling et al., 2014). It is also possible to tie this immune network into a larger Arabidopsis interaction network (Arabidopsis Interactome Mapping Consortium, 2011) and it has been observed that hubs targeted by effectors from multiple pathogens appear to be more likely to have a role in immunity. The next question naturally is therefore whether one can observe similar hubs in crops.

\section{TRANSCRIPTOMICS}

The Arabidopsis community has been greatly aided by the availability of post-genomic resources such as The Arabidopsis Information Resource ${ }^{2}$ (Rhee, 2003) and the Arabidopsis Information Portal $^{3}$, lab based tools such as whole genome microarrays (Aharoni and Vorst, 2002; Redman et al., 2004) and web tools such as 'genevestigator' (Zimmermann et al., 2004) and the 'Electronic Fluorescent Pictograph’ browser (Winter et al., 2007) for exploring large transcriptomic data sets and gene expression in different contexts. All of these resources have aided annotation of crop genomes, for example it was only in 2011 that the $1.2 \mathrm{~Gb}$ oilseed rape genome was dissected using transcriptome sequencing and the Arabidopsis genome as a reference for alignment (Bancroft et al., 2011).

One of the great benefits of these resources in models is the ability to perform in-depth studies of plant-pathogen interactions at the transcriptional level. For example, Thilmony et al. (2006) started to unravel manipulation of host transcription during Arabidopsis infection with the infectious Pseudomonas syringae strain DC3000 in addition to a Pseudomonas syringae hrpA mutant (compromised in its ability to deliver type III effector proteins (Collmer

${ }^{2}$ http://www.arabidopsis.org

${ }^{3}$ https://www.araport.org 
et al., 2000) and the Pseudomonas syringae DC3118 COR- mutant (defective in coronatine toxin production). This allowed them to begin separating host-mediated transcriptional changes from those caused by the action of pathogen effectors and virulence factors. Such studies are key to identifying 'desirable' transcriptional responses from the point of view of the host plant that can be used in future crop improvement applications. Models have also allowed detailed infection time courses to be performed, for example during Phytophthora capsici infection of tomato (Jupe et al., 2013b) and during Botrytis cinerea infection of Arabidopsis (Windram et al., 2012). These studies have given a detailed analysis of transcriptional reprogramming during colonization by a hemibiotrophic and necrotrophic pathogen respectively. The beauty of such approaches is that in addition to providing high-resolution transcriptional information that has facilitated the development of a plethora of bioinformatic tools (Brown et al., 2013; Polanski et al., 2014), it provides detailed insights into the chronology of infection, allowing clustering of similarly expressed genes. This in turn can be used for subsequent generation of network inference models (Penfold and Wild, 2011; Penfold et al., 2012). Such models enable the development of testable hypotheses as to the role and significance of specific genes in regulatory networks induced during biotic stress.

In addition, some studies are starting to link gene regulatory networks in Arabidopsis with that of crops. For example, by using conserved non-coding sequences it was possible to identify shared components of regulatory networks in Arabidopsis, papaya, poplar, and grape (Baxter et al., 2012). Recently, so-called transcription hubs have been identified either as targets of multiple effectors or transcriptional hubs regulating responses to pathogens (Windram et al., 2014) which give us potential targets for manipulation by new genome editing and synthetic biology technologies.

\section{LOOKING TO THE FUTURE: NEW TECHNOLOGIES FOR CROP IMPROVEMENT}

Through studying model plants and their pathogens, we have identified both protein and transcriptional hubs in plant immunity, which give us obvious targets for manipulation in crops. The plant community has two very promising tools to exploit for genome editing; the first of which is the transcription activator-like effector nuclease system (TALEN; Christian et al., 2010; Bogdanove and Voytas, 2011; Schornack et al., 2013) which utilizes the ability of TAL effectors from plant-pathogenic Xanthomonas species to bind short regions of DNA in a sequence specific manner (Boch et al., 2009) and modulate gene expression. The second tool is the clustered regulatory interspaced short palindromic repeat (CRISPR) system (Belhaj et al., 2013). This technology gives us the ability to create point mutations in genes without inserting extra unnecessary foreigner DNA. For example homozygous targeted gene knock-out plants were obtained at the first generation in tomato (Brooks et al., 2014) and is particularly important due to the skepticism of GM crops generally exhibited by the public.

In the last few years, many tools have been developed which allow the rapid cloning and assembly of modular constructs that would have been previously challenging. For example USER fusion, which utilizes uracil excision-based cloning (Geu-Flores et al., 2007), Golden Gate and golden gate-based systems such as golden braid (Engler et al., 2008; Sarrion-Perdigones et al., 2013). There are also molecular toolkits available (Binder et al., 2014; Engler et al., 2014) that allow rapid and flexible cloning. These technologies can be used both to complement existing $R$ gene mediated immunity by stacking $R$ genes in so-called resistance cassettes (multi-R-gene constructs), and in new synthetic biology approaches. Synthetic biology approaches have the exciting potential for designing inducible disease resistance in crops; it has been shown to be possible to engineer synthetic, stress responsive promoters in Arabidopsis (Hou et al., 2012). Our detailed knowledge of signaling in plant immunity, resulting form genetics, mutations, genomics and systems modeling will enable the construction of novel, resilient immune response networks in plants.

Synthetic biology can also be combined with existing tools; such as utilizing the DNA binding properties of TAL effectors for more than nuclease targeting. For example, since it is known that expression of the rice resistance gene $\mathrm{Xa27}$ is mediated through the presence of a TAL effector binding site for the effector avrXa27 (Gu et al., 2005), there is potential for engineering 'designer $R$ genes.' By using the TAL effector code there is potential to design several binding sites and engineer an $R$ gene that mounts resistance to several conserved pathogen effectors (reviewed in Grant et al., 2013).

These new techniques can help to tackle major challenges associated with crops, including polyploidy genomes (such as strawberries Galletta and Maas, 1990). For example TAL effector and CRISPR-based technology was used to successfully mutate the three homeoalleles of the powdery mildew susceptibility gene Mlo from the hexaploid wheat in order to prevent pathogen growth (Wang et al., 2014). In addition, we need to design plants that are able to respond to pathogen attack without developmental penalties and this looks to be achievable using synthetic biology approaches.

\section{CONCLUSION}

The use of plant models such as Arabidopsis and tomato has been instrumental in addressing the mechanisms of plant-microbe interactions. Models have especially helped formulate concepts to describe the plant immune system (Jones and Dangl, 2006). Due to the wide-range of pathogens able to infect these two model plants, and their different modes of infection, the scientific community has been able to dissect at the molecular level the dialog established between the host and its pathogen and comprehend what lies behind plant disease susceptibility and plant disease resistance. The elucidation of how PRRs and $\mathrm{R}$ proteins are activated and trigger downstream signaling to fulfill resistance has highlighted many key players to target for increased resistance in crop plants. However, overall knowledge transfer from basic research to crop plants has been rather limited (Table 1). There are not many examples that have made it to the level of commercial production and progress here has been disappointingly slow considering how much we have learned about plant innate immunity in recent years. The characterization of defense gene regulatory networks in model plants will be the next step that will expedites the transposition of knowledge into 
crops. The new tools of synthetic biology approaches will further enable plant breeders to engineer designer crops with inducible defenses against pathogens lacking the corresponding fitness costs that may make them unappealing to growers. The future challenge for plant pathology will be to leverage this increasing knowledge base in the models to engineer durable resistance in the major crop plants to sustain yield in the face of altering climatic conditions.

\section{ACKNOWLEDGMENTS}

This research was funded by the Biotechnology and Biological Science Research Council grants (BB/K018183/1) awarded to Jim L. Beynon and (BB/L019345/1) awarded to Vardis Ntoukakis. Vardis Ntoukakis is supported by the Royal Society.

\section{REFERENCES}

Afroz, A., Chaudhry, Z., Rashid, U., Ali, G. M., Nazir, F., Iqbal, J., et al. (2010). Enhanced resistance against bacterial wilt in transgenic tomato (Lycopersicon esculentum) lines expressing the Xa21 gene. Plant Cell Tissue Organ Cult. 104, 227-237. doi: 10.1007/s11240-010-9825-2

Aharoni, A., and Vorst, O. (2002). DNA microarrays for functional plant genomics. Plant Mol. Biol. 48, 99-118. doi: 10.1023/A:1013734019946

Alfano, J. R. (2009). Roadmap for future research on plant pathogen effectors. Mol. Plant Pathol. 10, 805-813. doi: 10.1111/j.1364-3703.2009.00588.x

Alonso, J. M., Stepanova, A. N., Leisse, T. J., Kim, C. J., Chen, H., Shinn, P., et al. (2003). Genome-wide insertional mutagenesis of Arabidopsis thaliana. Science 301, 653-657. doi: 10.1126/science.1086391

Andolfo, G., Jupe, F., Witek, K., Etherington, G. J., Ercolano, M. R., and Jones, J. D. G. (2014). Defining the full tomato NB-LRR resistance gene repertoire using genomic and cDNA RenSeq. BMC Plant Biol. 14:120. doi: 10.1186/1471-2229$14-120$

Andolfo, G., Sanseverino, W., Rombauts, S., Van de Peer, Y., Bradeen, J. M., Carputo, D., et al. (2013). Overview of tomato (Solanum lycopersicum) candidate pathogen recognition genes reveals important Solanum R locus dynamics. New Phytol. 197, 223-237. doi: 10.1111/j.1469-8137.2012.04380.x

Arabidopsis Interactome Mapping Consortium. (2011). Evidence for network evolution in an Arabidopsis interactome map. Science 333, 601-607. doi: $10.1126 /$ science. 1203877

Arie, T., Takahashi, H., Kodama, M., and Teraoka, T. (2007). Tomato as a model plant for plant-pathogen interactions. Plant Biotechnol. 24, 135-147. doi: 10.5511/plantbiotechnology.24.135

Ashfield, T., Danzer, J. R., Held, D., Clayton, K., Keim, P., Saghai Maroof, M. A., et al. (1998). Rpg1, a soybean gene effective against races of bacterial blight, maps to a cluster of previously identified disease resistance genes. Theor. Appl. Genet. 96, 1013-1021. doi: $10.1007 / \mathrm{s} 001220050833$

Ashfield, T., Keen, N. T., Buzzell, R. I., and Innes, R. W. (1995). Soybean resistance genes specific for different Pseudomonas syringae avirulence genes are allelic, or closely linked, at the RPG1 locus. Genetics 141, 1597-1604.

Assaad, F. F., Qiu, J.-L., Youngs, H., Ehrhardt, D., Zimmerli, L., Kalde, M., et al. (2004). The PEN1 syntaxin defines a novel cellular compartment upon fungal attack and is required for the timely assembly of papillae. Mol. Biol. Cell 15, 5118-5129. doi: 10.1091/mbc.E04-02-0140

Axtell, M. J., and Staskawicz, B. J. (2003). Initiation of RPS2-specified disease resistance in Arabidopsis is coupled to the AvrRpt2-directed elimination of RIN4. Cell 112, 369-377. doi: 10.1016/S0092-8674(03)00036-9

Ayliffe, M., Singh, R., and Lagudah, E. (2008). Durable resistance to wheat stem rust needed. Curr. Opin. Plant Biol. 11, 187-192. doi: 10.1016/j.pbi.2008.02.001

Baltrus, D. A., Nishimura, M. T., Romanchuk, A., Chang, J. H., Mukhtar, M. S., Cherkis, K., et al. (2011). Dynamic evolution of pathogenicity revealed by sequencing and comparative genomics of 19 Pseudomonas syringae isolates. PLoS Pathog. 7:e1002132. doi: 10.1371/journal.ppat.1002132

Bancroft, I., Morgan, C., Fraser, F., Higgins, J., Wells, R., Clissold, L., et al. (2011). Dissecting the genome of the polyploid crop oilseed rape by transcriptome sequencing. Nat. Biotechnol. 29, 762-766. doi: 10.1038/nbt.1926

Baxter, L., Jironkin, A., Hickman, R., Moore, J., Barrington, C., Krusche, P., et al. (2012). Conserved noncoding sequences highlight shared components of regulatory networks in dicotyledonous plants. Plant Cell 24, 3949-3965. doi: 10.1105/tpc.112.103010

Bebber, D. P., Ramotowski, M. A. T., and Gurr, S. J. (2013). Crop pests and pathogens move polewards in a warming world. Nat. Clim. Chang. 3, 985-988. doi: 10.1038/nclimate1990

Belhaj, K., Chaparro-Garcia, A., Kamoun, S., and Nekrasov, V. (2013). Plant genome editing made easy: targeted mutagenesis in model and crop plants using the CRISPR/Cas system. Plant Methods 9, 39. doi: 10.1186/1746-4811-9-39

Bent, A. F., Kunkel, B. N., Dahlbeck, D., Brown, K. L., Schmidt, R., Giraudat, J., et al. (1994). RPS2 of Arabidopsis thaliana: a leucine-rich repeat class of plant disease resistance genes. Science 265, 1856-1860. doi: 10.1126/science.8091210

Bernoux, M., Ve, T., Williams, S., Warren, C., Hatters, D., Valkov, E., et al. (2011). Structural and functional analysis of a plant resistance protein TIR domain reveals interfaces for self-association, signaling, and autoregulation. Cell Host Microbe 9, 200-211. doi: 10.1016/j.chom.2011.02.009

Biffen, R. H. (1905). Mendel's laws of inheritance and wheat breeding. J. Agric. Sci. 1, 4-48. doi: 10.1017/S0021859600000137

Binder, A., Lambert, J., Morbitzer, R., Popp, C., Ott, T., Lahaye, T., et al. (2014). A modular plasmid assembly kit for multigene expression, gene silencing and silencing rescue in plants. PLOS ONE 9:e88218. doi: 10.1371/journal.pone. 0088218

Birker, D., Heidrich, K., Takahara, H., Narusaka, M., Deslandes, L., Narusaka, Y., et al. (2009). A locus conferring resistance to Colletotrichum higginsianum is shared by four geographically distinct Arabidopsis accessions. Plant J. 60, 602-613. doi: 10.1111/j.1365-313X.2009.03984.x

Boch, J., Scholze, H., Schornack, S., Landgraf, A., Hahn, S., Kay, S., et al. (2009). Breaking the code of DNA binding specificity of TAL-type III effectors. Science 326, 1509-1512. doi: 10.1126/science.1178811

Bogdanove, A. J., and Voytas, D. F. (2011). TAL effectors: customizable proteins for DNA targeting. Science 333, 1843-1846. doi: 10.1126/science. 1204094

Bolton, M. D. (2009). Primary metabolism and plant defense-fuel for the fire. Mol. Plant Microbe Interact. 22, 487-497. doi: 10.1094/MPMI-22-5-0487

Bonardi, V., Cherkis, K., Nishimura, M. T., and Dangl, J. L. (2012). A new eye on NLR proteins: focused on clarity or diffused by complexity? Curr. Opin. Immunol. 24, 41-50. doi: 10.1016/j.coi.2011.12.006

Botella, M. A., Parker, J. E., Frost, L. N., Bittner-Eddy, P. D., Beynon, J. L., Daniels, M. J., et al. (1998). Three genes of the Arabidopsis RPP1 complex resistance locus recognize distinct Peronospora parasitica avirulence determinants. Plant Cell 10, 1847-1860. doi: 10.1105/tpc.10.11.1847

Bouwmeester, K., Han, M., Blanco-Portales, R., Song, W., Weide, R., Guo, L.-Y., et al. (2014). The Arabidopsis lectin receptor kinase LecRK-I.9 enhances resistance to Phytophthora infestans in Solanaceous plants. Plant Biotechnol. J. 12, 10-16. doi: $10.1111 /$ pbi.12111

Bozkurt, T. O., Schornack, S., Banfield, M. J., and Kamoun, S. (2012). Oomycetes, effectors, and all that jazz. Curr. Opin. Plant Biol. 15, 483-492. doi: 10.1016/j.pbi.2012.03.008

Brooks, C., Nekrasov, V., Lippman, Z. B., and Van Eck, J. (2014). Efficient gene editing in tomato in the first generation using the CRISPR/Cas9 system. Plant Physiol. 166, 1292-1297. doi: 10.1104/pp.114.247577

Brown, P., Baxter, L., Hickman, R., Beynon, J., Moore, J. D., and Ott, S. (2013). MEME-LaB: motif analysis in clusters. Bioinformatics 29, 1696-1697. doi: 10.1093/bioinformatics/btt248

Buell, C. R. (1998). Arabidopsis: a weed leading the field of plant-pathogen interactions. Plant Physiol. Biochem. 36, 177-186. doi: 10.1016/S0981-9428(98)80102-2

Butler, D. (2013). Fungus threatens top banana. Nature 504, 195-196. doi: $10.1038 / 504195 \mathrm{a}$

Cao, H., Bowling, S. A., Gordon, A. S., and Dong, X. (1994). Characterization of an Arabidopsis mutant that is nonresponsive to inducers of systemic acquired resistance. Plant Cell 6, 1583-1592. doi: 10.1105/tpc.6.11.1583

Carmona, M. A., Gally, M. E., and Lopez, S. E. (2005). Asian soybean rust: incidence, severity, and morphological characterization of Phakopsora pachyrhizi (Uredinia and Telia) in Argentina. Plant Dis. 89:109. doi: 10.1094/PD-890109B

Cesari, S., Thilliez, G., Ribot, C., Chalvon, V., Michel, C., Jauneau, A., et al. (2013). The rice resistance protein pair RGA4/RGA5 recognizes the Magnaporthe oryzae effectors AVR-Pia and AVR1-CO39 by direct binding. Plant Cell 25, 1463-1481. doi: $10.1105 /$ tpc.112.107201 
Childers, R., Danies, G., Myers, K. L., Fei, Z., Small, I. M., and Fry, W. (2014). Acquired resistance to mefenoxam in sensitive isolates of Phytophthora infestans. Phytopathology doi: 10.1094/PHYTO-05-14-0148-R [Epub ahead of print].

Chinchilla, D., Zipfel, C., Robatzek, S., Kemmerling, B., Nürnberger, T., Jones, J. D. G., et al. (2007). A flagellin-induced complex of the receptor FLS2 and BAK1 initiates plant defence. Nature 448, 497-500. doi: 10.1038/nature05999

Christian, M., Cermak, T., Doyle, E. L., Schmidt, C., Zhang, F., Hummel, A., et al. (2010). Targeting DNA double-strand breaks with TAL effector nucleases. Genetics 186, 757-761. doi: 10.1534/genetics.110.120717

Coates, M. E., and Beynon, J. L. (2010). Hyaloperonospora arabidopsidis as a pathogen model. Annu. Rev. Phytopathol. 48, 329-345. doi: 10.1146/annurevphyto-080508-094422

Collier, S. M., and Moffett, P. (2009). NB-LRRs work a "bait and switch" on pathogens. Trends Plant Sci. 14, 521-529. doi: 10.1016/j.tplants.2009.08.001

Collins, N. C., Thordal-Christensen, H., Lipka, V., Bau, S., Kombrink, E., Qiu, J.-L., et al. (2003). SNARE-protein-mediated disease resistance at the plant cell wall Nature 425, 973-977. doi: 10.1038/nature02076

Collmer, A., Badel, J. L., Charkowski, A. O., Deng, W. L., Fouts, D. E., Ramos, A. R., et al. (2000). Pseudomonas syringae Hrp type III secretion system and effector proteins. Proc. Natl. Acad. Sci. U.S.A. 97, 8770-8777. doi: 10.1073/pnas.97.16.8770

Conrath, U., Gollner, K., Langenbach, C., Schultheiss, H., and Tresch, N. (2013). Genes to Enhance the Disease Resistance in Crops. Patent number $\mathrm{WO} / 2013 / 093738$.

Cooper, A. J., Latunde-Dada, A. O., Woods-Tör, A., Lynn, J., Lucas, J. A., Crute, I. R., et al. (2008). Basic compatibility of Albugo candida in Arabidopsis thaliana and Brassica juncea causes broad-spectrum suppression of innate immunity. Mol. Plant Microbe Interact. 21, 745-756. doi: 10.1094/MPMI-21-6-0745

Crute, I., Beynon, J., Dangl, J., Holub, E., Mauch-Mani, B., Slusarenko, A., et al. (1994). "Microbial pathogenesis of Arabidopsis," in Arabidopsis, eds E. M. Meyerowitz and C. R. Somerville (Newyork, NY: Cold Spring Harbor Laboratory Press), 705-747.

Dangl, J. L., Horvath, D. M., and Staskawicz, B. J. (2013). Pivoting the plant immune system from dissection to deployment. Science 341, 746-751. doi: $10.1126 /$ science. 1236011

Dangl, J. L., and Jones, J. D. (2001). Plant pathogens and integrated defence responses to infection. Nature 411, 826-833. doi: 10.1038/35081161

Deslandes, L., Olivier, J., Peeters, N., Feng, D. X., Khounlotham, M., Boucher, C., et al. (2003). Physical interaction between RRS1-R, a protein conferring resistance to bacterial wilt, and PopP2, a type III effector targeted to the plant nucleus. Proc. Natl. Acad. Sci. U.S.A. 100, 8024-8029. doi: 10.1073/pnas. 1230660100

Dixon, M. S., Jones, D. A., Keddie, J. S., Thomas, C. M., Harrison, K., and Jones, J. D. (1996). The tomato Cf-2 disease resistance locus comprises two functional genes encoding leucine-rich repeat proteins. Cell 84, 451-459. doi: 10.1016/S00928674(00)81290-8

Dodds, P. N., Lawrence, G. J., Catanzariti, A.-M., Teh, T., Wang, C.-I. A., Ayliffe, M. A., et al. (2006). Direct protein interaction underlies gene-for-gene specificity and coevolution of the flax resistance genes and flax rust avirulence genes. Proc. Natl. Acad. Sci. U.S.A. 103, 8888-8893. doi: 10.1073/pnas.0602577103

Eitas, T. K., and Dangl, J. L. (2010). NB-LRR proteins: pairs, pieces, perception, partners, and pathways. Curr. Opin. Plant Biol. 13, 472-477. doi: 10.1016/j.pbi.2010.04.007

El Oirdi, M., El Rahman, T. A., Rigano, L., El Hadrami, A., Rodriguez, M. C., Daayf, F., et al. (2011). Botrytis cinerea manipulates the antagonistic effects between immune pathways to promote disease development in tomato. Plant Cell 23, 2405-2421. doi: 10.1105/tpc.111.083394

Engler, C., Kandzia, R., and Marillonnet, S. (2008). A one pot, one step, precision cloning method with high throughput capability. PLoS ONE 3:e3647. doi: 10.1371/journal.pone.0003647

Engler, C., Youles, M., Gruetzner, R., Ehnert, T.-M., Werner, S., Jones, J. D. G., et al. (2014). A golden gate modular cloning toolbox for plants. ACS Synth. Biol. doi: $10.1021 / \mathrm{sb} 4001504$

Escobar, M. A., Civerolo, E. L., Summerfelt, K. R., and Dandekar, A. M. (2001). RNAi-mediated oncogene silencing confers resistance to crown gall tumorigenesis. Proc. Natl. Acad. Sci. U.S.A. 98, 13437-13442. doi: 10.1073/pnas. 241276898

FAOSTAT. (2012). Food and Agriculture Organization of the United Nations. Available at: http://faostat.fao.org (accessed September 11, 2014).
Farnham, G., and Baulcombe, D. C. (2006). Artificial evolution extends the spectrum of viruses that are targeted by a disease-resistance gene from potato. Proc. Natl. Acad. Sci. U.S.A. 103, 18828-18833. doi: 10.1073/pnas.0605777103

Finkelstein, R. R. (1994). Mutations at two new Arabidopsis ABA response loci are similar to the abi3 mutations. Plant J. 5, 765-771. doi: 10.1046/j.1365313X.1994.5060765.X

Fisher, M. C., Henk, D. A., Briggs, C. J., Brownstein, J. S., Madoff, L. C., McCraw, S. L., et al. (2012). Emerging fungal threats to animal, plant and ecosystem health. Nature 484, 186-194. doi: 10.1038/nature10947

Flor, H. H. (1955). Host-parasite interaction in flax rust - its genetics and other implications. Phytopathology 45, 680-685.

Flor, H. H. (1971). Current status of the gene-for-gene concept. Annu. Rev. Phytopathol. 9, 275-296. doi: 10.1146/annurev.py.09.090171.001423

Fradin, E. F., Abd-El-Haliem, A., Masini, L., van den Berg, G. C. M., Joosten, M. H., and Thomma, B. P. (2011). Interfamily transfer of tomato Vel mediates Verticillium resistance in Arabidopsis. Plant Physiol. 156, 2255-2265. doi: 10.1104/pp.111.180067

Fradin, E. F., Zhang, Z., Juarez Ayala, J. C., Castroverde, C. D. M., Nazar, R. N., Robb, J., et al. (2009). Genetic dissection of Verticillium wilt resistance mediated by tomato Ve1. Plant Physiol. 150, 320-332. doi: 10.1104/pp.109.136762

Fritz-Laylin, L. K., Krishnamurthy, N., Tor, M., Sjolander, K. V., and Jones, J. D. G. (2005). Phylogenomic analysis of the receptor-like proteins of rice and Arabidopsis. Plant Physiol. 138, 611-623. doi: 10.1104/pp.104.054452

Galletta, G. J., and Maas, J. L. (1990). Strawberry genetics. HortScience 25, 871-879.

Geu-Flores, F., Nour-Eldin, H. H., Nielsen, M. T., and Halkier, B. A. (2007). USER fusion: a rapid and efficient method for simultaneous fusion and cloning of multiple PCR products. Nucleic Acids Res. 35:e55. doi: 10.1093/nar/gkm106

Gimenez-Ibanez, S., Hann, D. R., Ntoukakis, V., Petutschnig, E., Lipka, V., and Rathjen, J. P. (2009). AvrPtoB targets the LysM receptor kinase CERK1 to promote bacterial virulence on plants. Curr. Biol. 19, 423-429. doi: 10.1016/j.cub.2009.01.054

Giovannoni, J. (2001). Molecular biology of fruit maturation and ripening. Annu. Rev. Plant Physiol. Plant Mol. Biol. 52, 725-749. doi: 10.1146/annurev. arplant.52.1.725

Giovannoni, J. (2004). Genetic regulation of fruit development and ripening. Plant Cell 16(Suppl.), S170-S180. doi: 10.1105/tpc.019158

Glazebrook, J. (2005). Contrasting mechanisms of defense against biotrophic and necrotrophic pathogens. Annu. Rev. Phytopathol. 43, 205-227. doi: 10.1146/annurev.phyto.43.040204.135923

Glazebrook, J., Rogers, E. E., and Ausubel, F. M. (1996). Isolation of Arabidopsis mutants with enhanced disease susceptibility by direct screening. Genetics 143, 973-982.

Göhre, V., Jones, A. M. E., Sklenar, J., Robatzek, S., and Weber, A. P. M. (2012). Molecular crosstalk between PAMP-triggered immunity and photosynthesis. Mol. Plant Microbe Interact. 25, 1083-1092. doi: 10.1094/MPMI-11-11-0301

Göhre, V., Spallek, T., Häweker, H., Mersmann, S., Mentzel, T., Boller, T., et al. (2008). Plant pattern-recognition receptor FLS2 is directed for degradation by the bacterial ubiquitin ligase AvrPtoB. Curr. Biol. 18, 1824-1832. doi: 10.1016/j.cub.2008.10.063

Gómez-Gómez, L., and Boller, T. (2000). FLS2: an LRR receptor-like kinase involved in the perception of the bacterial elicitor flagellin in Arabidopsis. Mol. Cell 5, 1003-1011. doi: 10.1016/S1097-2765(00)80265-8

Grant, M. R., Godiard, L., Straube, E., Ashfield, T., Lewald, J., Sattler, A., etal. (1995). Structure of the Arabidopsis RPM1 gene enabling dual specificity disease resistance. Science 269, 843-846. doi: 10.1126/science.76 38602

Grant, M. R., Kazan, K., and Manners, J. M. (2013). Exploiting pathogens' tricks of the trade for engineering of plant disease resistance: challenges and opportunities. Microb. Biotechnol. 6, 212-222. doi: 10.1111/1751-7915.12017

Greene, E. A., Codomo, C. A., Taylor, N. E., Henikoff, J. G., Till, B. J., Reynolds, S. H., et al. (2003). Spectrum of chemically induced mutations from a large-scale reverse-genetic screen in Arabidopsis. Genetics 164, 731-740.

Grzeskowiak, L., Stephan, W., and Rose, L. E. (2014). Epistatic selection and coadaptation in the Prf resistance complex of wild tomato. Infect. Genet. Evol. 27, 456-471. doi: 10.1016/j.meegid.2014.06.019

Gu, K., Yang, B., Tian, D., Wu, L., Wang, D., Sreekala, C., et al. (2005). R gene expression induced by a type-III effector triggers disease resistance in rice. Nature 435, 1122-1125. doi: 10.1038/nature 03630 
Gutierrez, J. R., Balmuth, A. L., Ntoukakis, V., Mucyn, T. S., Gimenez-Ibanez, S., Jones, A. M. E., et al. (2010). Prf immune complexes of tomato are oligomeric and contain multiple Pto-like kinases that diversify effector recognition. Plant J. 61, 507-518. doi: 10.1111/j.1365-313X.2009.04078.x

Guttman, D. S., Vinatzer, B. A., Sarkar, S. F., Ranall, M. V., Kettler, G., and Greenberg, J. T. (2002). A functional screen for the Type III (Hrp) secretome of the plant pathogen Pseudomonas syringae. Science 295, 1722-1726. doi: $10.1126 /$ science.295.5560.1722

Haas, B. J., Kamoun, S., Zody, M. C., Jiang, R. H. Y., Handsaker, R. E., Cano, L. M., et al. (2009). Genome sequence and analysis of the Irish potato famine pathogen Phytophthora infestans. Nature 461, 393-398. doi: 10.1038/nature08358

Hahn, M. (2014). The rising threat of fungicide resistance in plant pathogenic fungi: Botrytis as a case study. J. Chem. Biol. 7, 133-141. doi: 10.1007/s12154-014-0113-1

Hao, Y., Wang, X., Li, X., Bassa, C., Mila, I., Audran, C., et al. (2014). Genome-wide identification, phylogenetic analysis, expression profiling, and protein-protein interaction properties of TOPLESS gene family members in tomato. J. Exp. Bot. 65, 1013-1023. doi: 10.1093/jxb/ert440

Harris, C. J., Slootweg, E. J., Goverse, A., and Baulcombe, D. C. (2013). Stepwise artificial evolution of a plant disease resistance gene. Proc. Natl. Acad. Sci. U.S.A 110, 21189-21194. doi: 10.1073/pnas.1311134110

Haverkort, A. J., Boonekamp, P. M., Hutten, R., Jacobsen, E., Lotz, L. A. P., Kessel, G. J. T., et al. (2008). Societal costs of late blight in potato and prospects of durable resistance through cisgenic modification. Potato Res. 51, 47-57. doi: 10.1007/s11540-008-9089-y

Heath, M. C. (1981). A generalized concept of host-parasite specificity. Phytopathology 71, 1121-1123. doi: 10.1094/Phyto-71-1121

Heese, A., Hann, D. R., Gimenez-Ibanez, S., Jones, A. M. E., He, K., Li, J., et al. (2007). The receptor-like kinase SERK3/BAK1 is a central regulator of innate immunity in plants. Proc. Natl. Acad. Sci. U.S.A. 104, 12217-12222. doi: 10.1073/pnas.0705306104

Heidel, A. J., Clarke, J. D., Antonovics, J., and Dong, X. (2004). Fitness costs of mutations affecting the systemic acquired resistance pathway in Arabidopsis thaliana. Genetics 168, 2197-2206. doi: 10.1534/genetics.104.032193

Holub, E. B. (2007). Natural variation in innate immunity of a pioneer species. Curr. Opin. Plant Biol. 10, 415-424. doi: 10.1016/j.pbi.2007.05.003

Holub, E. B. (2008). Natural history of Arabidopsis thaliana and oomycete symbioses. Eur. J. Plant Pathol. 122, 91-109. doi:10.1007/s10658-008-9286-1

Holub, E. B., and Beynon, J. L. (1997). Symbiology of mouse-ear cress (Arabidopsis thaliana) and oomycetes. Adv. Bot. Res. 24, 227-269. doi: 10.1016/S00652296(08)60075-0

Holub, E. B., Brose, E., Tör, M., Clay, C., Crute, I. R., and Beynon, J. L. (1995). Phenotypic and genotypic variation in the interaction between Arabidopsis thaliana and Albugo candida. Mol. Plant Microbe Interact. 8, 916-928. doi: 10.1094/MPMI-8-0916

Horvath, D. M., Stall, R. E., Jones, J. B., Pauly, M. H., Vallad, G. E., Dahlbeck, D., et al. (2012). Transgenic resistance confers effective field level control of bacterial spot disease in tomato. PLoS ONE 7:e42036. doi: 10.1371/journal.pone. 0042036

Hou, L., Chen, L., Wang, J., Xu, D., Dai, L., Zhang, H., et al. (2012). Construction of stress responsive synthetic promoters and analysis of their activity in transgenic Arabidopsis thaliana. Plant Mol. Biol. Rep. 30, 1496-1506. doi: 10.1007/s11105012-0464-0

Hrabak, E. M., Chan, C. W. M., Gribskov, M., Harper, J. F., Choi, J. H., Halford, N., et al. (2003). The Arabidopsis CDPK-SnRK superfamily of protein kinases. Plant Physiol. 132, 666-680. doi: 10.1104/pp.102.011999

Huai, J., Wang, M., He, J., Zheng, J., Dong, Z., Lv, H., et al. (2008). Cloning and characterization of the SnRK2 gene family from Zea mays. Plant Cell Rep. 27, 1861-1868. doi: 10.1007/s00299-008-0608-8

Huang, G., Allen, R., Davis, E. L., Baum, T. J., and Hussey, R. S. (2006). Engineering broad root-knot resistance in transgenic plants by RNAi silencing of a conserved and essential root-knot nematode parasitism gene. Proc. Natl. Acad. Sci. U.S.A. 103, 14302-14306. doi: 10.1073/pnas.0604698103

Huitema, E., Vleeshouwers, V. G., Francis, D. M., and Kamoun, S. (2003). Active defence responses associated with non-host resistance of Arabidopsis thaliana to the oomycete pathogen Phytophthora infestans. Mol. Plant Pathol. 4, 487-500. doi: 10.1046/j.1364-3703.2003.00195.x

Innes, R. W., Bisgrove, S. R., Smith, N. M., Bent, A. F., Staskawicz, B. J., and Liu, Y. C. (1993). Identification of a disease resistance locus in Arabidopsis that is functionally homologous to the RPG1 locus of soybean. Plant J. 4, 813-820. doi: 10.1046/j.1365-313X.1993.04050813.x

Jakob, K., Goss, E. M., Araki, H., Van, T., Kreitman, M., and Bergelson, J. (2002). Pseudomonas viridiflava and P. syringae - natural pathogens of Arabidopsis thaliana. Mol. Plant Microbe Interact. 15, 1195-1203. doi: 10.1094/MPMI.2002.15.12.1195

Jia, Y., McAdams, S. A., Bryan, G. T., Hershey, H. P., and Valent, B. (2000). Direct interaction of resistance gene and avirulence gene products confers rice blast resistance. EMBO J. 19, 4004-4014. doi: 10.1093/emboj/19.15.4004

Jo, K.-R., Kim, C.-J., Kim, S.-J., Kim, T.-Y., Bergervoet, M., Jongsma, M. A., et al. (2014). Development of late blight resistant potatoes by cisgene stacking. BMC Biotechnol. 14:50. doi: 10.1186/1472-6750-14-50

Johnson, R., and Allen, D. J. (1975). Induced resistance to rust diseases and its possible role in the resistance of multiline varieties. Annu. Appl. Biol. 80, 359-363. doi: 10.1111/j.1744-7348.1975.tb01642.x

Jones, D. A., Thomas, C. M., Hammond-Kosack, K. E., Balint-Kurti, P. J., and Jones, J. D. (1994). Isolation of the tomato Cf-9 gene for resistance to Cladosporium fulvum by transposon tagging. Science 266, 789-793. doi: 10.1126/science.7973631

Jones, J. B., Jones, J. P., Stall, R. E., and Zitter, T. A. (1991). Compendium of Tomato 1094 Diseases. St Paul, MN: APS Press.

Jones, J. D. G., and Dangl, J. L. (2006). The plant immune system. Nature 444, 323-329. doi: 10.1038/nature05286

Jones, J. D. G., Witek, K., Verweij, W., Jupe, F., Cooke, D., Dorling, S., et al. (2014). Elevating crop disease resistance with cloned genes. Philos. Trans. R. Soc. Lond. B Biol. Sci. 369:20130087. doi: 10.1098/rstb.2013.0087

Jupe, F., Witek, K., Verweij, W., Sliwka, J., Pritchard, L., Etherington, G. J., et al. (2013a). Resistance gene enrichment sequencing (RenSeq) enables reannotation of the NB-LRR gene family from sequenced plant genomes and rapid mapping of resistance loci in segregating populations. Plant J. 76, 530-544. doi: $10.1111 /$ tpj.12307

Jupe, J., Stam, R., Howden, A. J. M., Morris, J. A., Zhang, R., Hedley, P. E., et al. (2013b). Phytophthora capsici-tomato interaction features dramatic shifts in gene expression associated with a hemi-biotrophic lifestyle. Genome Biol. 14:R63. doi: 10.1186/gb-2013-14-6-r63

Kim, H.-J., Lee, H.-R., Jo, K.-R., Mortazavian, S. M. M., Huigen, D. J., Evenhuis, B., et al. (2012). Broad spectrum late blight resistance in potato differential set plants MaR8 and MaR9 is conferred by multiple stacked R genes. Theor. Appl. Genet. 124, 923-935. doi: 10.1007/s00122-011-1757-7

Kim, Y. J., Lin, N.-C., and Martin, G. B. (2002). Two distinct Pseudomonas effector proteins interact with the Pto kinase and activate plant immunity. Cell 109, 589598. doi: 10.1016/S0092-8674(02)00743-2

Kobayashi, D. Y., Tamaki, S. J., and Keen, N. T. (1989). Cloned avirulence genes from the tomato pathogen Pseudomonas syringae pv. tomato confer cultivar specificity on soybean. Proc. Natl. Acad. Sci. U.S.A. 86, 157-161. doi: 10.1073/pnas.86.1.157

Koch, A., Kumar, N., Weber, L., Keller, H., Imani, J., and Kogel, K.-H. (2013). Host-induced gene silencing of cytochrome P450 lanosterol C14 $\alpha$-demethylaseencoding genes confers strong resistance to Fusarium species. Proc. Natl. Acad. Sci. U.S.A. 110, 19324-19329. doi: 10.1073/pnas.1306373110

Kohm, B. A., Goulden, M. G., Gilbert, J. E., Kavanagh, T. A., and Baulcombe, D. C. (1993). A potato virus $X$ resistance gene mediates an induced, nonspecific resistance in protoplasts. Plant Cell 5, 913-920. doi: 10.1105/tpc.5.8.913

Koornneef, M., and Meinke, D. (2010). The development of Arabidopsis as a model plant. Plant J. 61, 909-921. doi: 10.1111/j.1365-313X.2009.04086.x

Koornneef, M., Reuling, G., and Karssen, C. M. (1984). The isolation and characterization of abscisic acid-insensitive mutants of Arabidopsis thaliana. Physiol. Plant 61, 377-383. doi: 10.1111/j.1399-3054.1984.tb06343.x

Krasileva, K. V., Dahlbeck, D., and Staskawicz, B. J. (2010). Activation of an Arabidopsis resistance protein is specified by the in planta association of its leucine-rich repeat domain with the cognate oomycete effector. Plant Cell 22, 2444-2458. doi: $10.1105 /$ tpc. 110.075358

Lacombe, S., Rougon-Cardoso, A., Sherwood, E., Peeters, N., Dahlbeck, D., van Esse, H. P., et al. (2010). Interfamily transfer of a plant pattern-recognition receptor confers broad-spectrum bacterial resistance. Nat. Biotechnol. 28, 365-369. doi: $10.1038 /$ nbt. 1613

Langenbach, C., Campe, R., Schaffrath, U., Goellner, K., and Conrath, U. (2013). UDP-glucosyltransferase UGT84A2/BRT1 is required for Arabidopsis nonhost resistance to the Asian soybean rust pathogen Phakopsora pachyrhizi. New Phytol. 198, 536-545. doi: 10.1111/nph.12155 
Li, J., Wen, J., Lease, K. A., Doke, J. T., Tax, F. E., and Walker, J. C. (2002). BAK1, an Arabidopsis LRR receptor-like protein kinase, interacts with BRI1 and modulates brassinosteroid signaling. Cell 110, 213-222. doi: 10.1016/S0092-8674(02) 00812-7

Li, L.-B., Zhang, Y.-R., Liu, K.-C., Ni, Z.-F., Fang, Z.-J., Sun, Q.-X., et al. (2010). Identification and bioinformatics analysis of SnRK2 and CIPK family genes in sorghum. Agric. Sci. China 9, 19-30. doi: 10.1016/S1671-2927(09)60063-8

Lindeberg, M., Cunnac, S., and Collmer, A. (2012). Pseudomonas syringae type III effector repertoires: last words in endless arguments. Trends Microbiol. 20, 199-208. doi: 10.1016/j.tim.2012.01.003

Lipka, V., Dittgen, J., Bednarek, P., Bhat, R., Wiermer, M., Stein, M., et al. (2005). Pre- and postinvasion defenses both contribute to nonhost resistance in Arabidopsis. Science 310, 1180-1183. doi: 10.1126/science.1119409

Liu, Q., Rimmer, S. R., and Scarth, R. (1989). Histopathology of compatibility and incompatibility between oilseed rape and Albugo candida. Plant Pathol. 38, 176-182. doi: 10.1111/j.1365-3059.1989.tb02131.x

Loehrer, M., Langenbach, C., Goellner, K., Conrath, U., and Schaffrath, U. (2008) Characterization of nonhost resistance of Arabidopsis to the Asian soybean rust. Mol. Plant Microbe Interact. 21, 1421-1430. doi: 10.1094/MPMI-21-11-1421

Long, J. A., Woody, S., Poethig, S., Meyerowitz, E. M., and Barton, M. K. (2002). Transformation of shoots into roots in Arabidopsis embryos mutant at the TOPLESS locus. Development 129, 2797-2806.

Lozano-Durán, R., Macho, A. P., Boutrot, F., Segonzac, C., Somssich, I. E., and Zipfel, C. (2013). The transcriptional regulator BZR1 mediates trade-off between plant innate immunity and growth. Elife 2:e00983. doi: 10.7554/eLife.00983

Luna, E., Bruce, T. J. A., Roberts, M. R., Flors, V., and Ton, J. (2012). Nextgeneration systemic acquired resistance. Plant Physiol. 158, 844-853. doi: $10.1104 /$ pp. 111.187468

Macho, A. P., Schwessinger, B., Ntoukakis, V., Brutus, A., Segonzac, C., Roy, S., et al. (2014). A bacterial tyrosine phosphatase inhibits plant pattern recognition receptor activation. Science 343, 1509-1512. doi: 10.1126/science.1248849

Mackey, D., Belkhadir, Y., Alonso, J. M., Ecker, J. R., and Dangl, J. L. (2003). Arabidopsis RIN4 is a target of the type III virulence effector AvrRpt2 and modulates RPS2-mediated resistance. Cell 112, 379-389. doi: 10.1016/S00928674(03)00040-0

Mackey, D., Holt, B. F., Wiig, A., and Dangl, J. L. (2002). RIN4 interacts with Pseudomonas syringae type III effector molecules and is required for RPM1-mediated resistance in Arabidopsis. Cell 108, 743-754. doi: 10.1016/S0092-8674(02) 00661-X

Maekawa, T., Cheng, W., Spiridon, L. N., Töller, A., Lukasik, E., Saijo, Y., et al. (2011). Coiled-coil domain-dependent homodimerization of intracellular barley immune receptors defines a minimal functional module for triggering cell death. Cell Host Microbe 9, 187-199. doi: 10.1016/j.chom.2011.02.008

Maekawa, T., Kracher, B., Vernaldi, S., Ver Loren van Themaat, E., and Schulze-Lefert, P. (2012). Conservation of NLR-triggered immunity across plant lineages. Proc. Natl. Acad. Sci. U.S.A. 109, 20119-20123. doi: 10.1073/pnas. 1218059109

Marco, G. M., and Stall, R. E. (1983). Control of bacterial spot of pepper initiated by strains of Xanthomonas campestris pv. vesicatoria that differ in sensitivity to copper. Plant Dis. 67, 779-781. doi: 10.1094/PD-67-779

Martin, G. B., Brommonschenkel, S. H., Chunwongse, J., Frary, A., Ganal, M. W., Spivey, R., etal. (1993). Map-based cloning of a protein kinase gene conferring disease resistance in tomato. Science 262, 1432-1436. doi $10.1126 /$ science.7902614

Marumo, S., Katayama, M., Komori, E., Ozaki, Y., Natsume, M., and Kondo, S. (1982). Microbial production of abscisic acid by Botrytis cinerea. Agric. Biol. Chem. 46, 1967-1968. doi: 10.1271/bbb1961.46.1967

Mauch-Mani, B., and Slusarenko, A. J. (1993). Arabidopsis as a model host for studying plant-pathogen interactions. Trends Microbiol. 1, 265-270. doi: 10.1016/0966-842X(93)90049-W

McLellan, H., Boevink, P. C., Armstrong, M. R., Pritchard, L., Gomez, S., Morales, J., et al. (2013). An RxLR effector from Phytophthora infestans prevents re-localisation of two Plant NAC transcription factors from the endoplasmic reticulum to the nucleus. PLoS Pathog. 9:e1003670. doi: 10.1371/journal.ppat.1003670

Mendes, B., Cardoso, S. C., Boscariol-Camargo, R. L., Cruz, R. B., Mourão Filho, F., and Bergamin Filho, A. (2010). Reduction in susceptibility to Xanthomonas axonopodis pv. citri in transgenic Citrus sinensis expressing the rice Xa21 gene. Plant Pathol. 59, 68-75. doi: 10.1111/j.1365-3059.2009.02148.x
Mestre, P., and Baulcombe, D. C. (2006). Elicitor-mediated oligomerization of the tobacco $\mathrm{N}$ disease resistance protein. Plant Cell 18, 491-501. doi: 10.1105/tpc.105.037234

Meyers, B. C., Kozik, A., Griego, A., Kuang, H., and Michelmore, R. W. (2003). Genome-wide analysis of NBS-LRR-encoding genes in Arabidopsis. Plant Cell 15, 809-834. doi: 10.1105/tpc.009308

Mindrinos, M., Katagiri, F., Yu, G. L., and Ausubel, F. M. (1994). The A. thaliana disease resistance gene RPS2 encodes a protein containing a nucleotide-binding site and leucine-rich repeats. Cell 78, 1089-1099. doi: 10.1016/0092-8674(94)90282-8

Mucyn, T. S., Clemente, A., Andriotis, V. M. E., Balmuth, A. L., Oldroyd, G. E. D., Staskawicz, B. J., et al. (2006). The tomato NBARC-LRR protein Prf interacts with Pto kinase in vivo to regulate specific plant immunity. Plant Cell 18, 2792-2806. doi: 10.1105/tpc.106.044016

Mucyn, T. S., Wu, A. J., Balmuth, A. L., Arasteh, J. M., and Rathjen, J. P. (2009). Regulation of tomato Prf by Pto-Like protein kinases. Mol. Plant Microbe. Interact. 22, 391-401. doi: 10.1094/MPMI-22-4-0391

Mukhtar, M. S., Carvunis, A.-R., Dreze, M., Epple, P., Steinbrenner, J., Moore, J., et al. (2011). Independently evolved virulence effectors converge onto hubs in a plant immune system network. Science 333, 596-601. doi: 10.1126/science.1203659

Nakashima, K., Takasaki, H., Mizoi, J., Shinozaki, K., and Yamaguchi-Shinozaki, K. (2012). NAC transcription factors in plant abiotic stress responses. Biochim. Biophys. Acta 1819, 97-103. doi: 10.1016/j.bbagrm.2011.10.005

Narusaka, M., Hatakeyama, K., Shirasu, K., and Narusaka, Y. (2014). Arabidopsis dual resistance proteins, both RPS4 and RRS1, are required for resistance to bacterial wilt in transgenic Brassica crops. Plant Signal. Behav. 9:e29130. doi: $10.4161 /$ psb. 29130

Narusaka, M., Kubo, Y., Hatakeyama, K., Imamura, J., Ezura, H., Nanasato, Y., et al. (2013a). Interfamily transfer of dual NB-LRR genes confers resistance to multiple pathogens. PLoS ONE 8:e55954. doi: 10.1371/journal.pone.0055954

Narusaka, M., Kubo, Y., Hatakeyama, K., Imamura, J., Ezura, H., Nanasato, Y., et al. (2013b). Breaking restricted taxonomic functionality by dual resistance genes. Plant Signal. Behav. 8:e24244. doi: 10.4161/psb.24244

Narusaka, M., Shirasu, K., Noutoshi, Y., Kubo, Y., Shiraishi, T., Iwabuchi, M., et al. (2009). RRS1 and RPS4 provide a dual resistance-gene system against fungal and bacterial pathogens. Plant J. 60, 218-226. doi: 10.1111/j.1365-313X.2009.03949.x

Nicaise, V., Joe, A., Jeong, B.-R., Korneli, C., Boutrot, F., Westedt, I., et al (2013). Pseudomonas HopU1 modulates plant immune receptor levels by blocking the interaction of their mRNAs with GRP7. EMBO J. 32, 701-712. doi: 10.1038/emboj.2013.15

Ntoukakis, V., Balmuth, A. L., Mucyn, T. S., Gutierrez, J. R., Jones, A. M. E., and Rathjen, J. P. (2013). The tomato Prf complex is a molecular trap for bacterial effectors based on Pto transphosphorylation. PLoS Pathog. 9:e1003123. doi: 10.1371/journal.ppat.1003123

Ntoukakis, V., Mucyn, T. S., Gimenez-Ibanez, S., Chapman, H. C., Gutierrez, J. R., Balmuth, A. L., etal. (2009). Host inhibition of a bacterial virulence effector triggers immunity to infection. Science 324, 784-787. doi: $10.1126 /$ science. 1169430

Ntoukakis, V., Saur, I. M., Conlan, B., and Rathjen, J. P. (2014). The changing of the guard: the Pto/Prf receptor complex of tomato and pathogen recognition. Curr. Opin. Plant Biol. 20, 69-74. doi: 10.1016/j.pbi.2014.04.002

O'Brien, H. E., Thakur, S., and Guttman, D. S. (2011). Evolution of plant pathogenesis in Pseudomonas syringae: a genomics perspective. Annu. Rev. Phytopathol. 49, 269-289. doi: 10.1146/annurev-phyto-072910-095242

Oerke, E. C. (2006). Crop losses to pests. J. Agric. Sci. 144, 31-43. doi: $10.1017 /$ S0021859605005708

Osmont, K. S., and Hardtke, C. S. (2008). The topless plant developmental phenotype explained! Genome Biol. 9, 219. doi: 10.1186/gb-2008-9-4-219

Parker, J. E., Holub, E. B., Frost, L. N., Falk, A., Gunn, N. D., and Daniels, M. J. (1996). Characterization of eds1, a mutation in Arabidopsis suppressing resistance to Peronospora parasitica specified by several different RPP genes. Plant Cell 8, 2033-2046. doi: 10.1105/tpc.8.11.2033

Pauwels, L., Barbero, G. F., Geerinck, J., Tilleman, S., Grunewald, W., Pérez, A. C., et al. (2010). NINJA connects the co-repressor TOPLESS to jasmonate signalling. Nature 464, 788-791. doi: 10.1038/nature08854

Penfold, C. A., Buchanan-Wollaston, V., Denby, K. J., and Wild, D. L. (2012). Nonparametric Bayesian inference for perturbed and orthologous gene regulatory networks. Bioinformatics 28, i233-i241. doi: 10.1093/bioinformatics/ bts 222 
Penfold, C. A., and Wild, D. L. (2011). How to infer gene networks from expression profiles, revisited. Interface Focus 1, 857-870. doi: 10.1098/rsfs.2011.0053

Pennisi, E. (2010). Armed and dangerous. Science 327, 804-805. doi: 10.1126/science.327.5967.804

Petersen, M., Brodersen, P., Naested, H., Andreasson, E., Lindhart, U., Johansen, B., et al. (2000). Arabidopsis MAP kinase 4 negatively regulates systemic acquired resistance. Cell 103, 1111-1120. doi: 10.1016/S0092-8674(00)00213-0

Petnicki-Ocwieja, T., Schneider, D. J., Tam, V. C., Chancey, S. T., Shan, L., Jamir Y., et al. (2002). Genomewide identification of proteins secreted by the Hrp type III protein secretion system of Pseudomonas syringae pv. tomato DC3000. Proc Natl. Acad. Sci. U.S.A. 99, 7652-757. doi: 10.1073/pnas.112183899

Pivonia, S., Yang, X. B., and Pan, Z. (2005). Assessment of epidemic potential of soybean rust in the United States. Plant Dis. 89, 678-682. doi: 10.1094/PD89-0678

Polanski, K., Rhodes, J., Hill, C., Zhang, P., Jenkins, D. J., Kiddle, S. J., et al. (2014). Wigwams: identifying gene modules co-regulated across multiple biological conditions. Bioinformatics 30, 962-970. doi: 10.1093/bioinformatics/btt728

Pound, G. S., and Williams, P. H. (1963). Biological races of Albugo candida. Phytopathology 53, 1146-1149.

Redman, J. C., Haas, B. J., Tanimoto, G., and Town, C. D. (2004). Development and evaluation of an Arabidopsis whole genome Affymetrix probe array. Plant J. 38, 545-561. doi: 10.1111/j.1365-313X.2004.02061.x

Rédei, G. P., and Koncz, C. (1992). Classical Mutagenesis. Methods in Arabidopsis Research. Singapore: World Scientific Publishing Co.

Rhee, S. Y. (2003). The Arabidopsis Information Resource (TAIR): a mode organism database providing a centralized, curated gateway to Arabidopsis biology, research materials and community. Nucleic Acids Res. 31, 224-228. doi 10.1093/nar/gkg076

Robert-Seilaniantz, A., Grant, M., and Jones, J. D. G. (2011). Hormone crosstalk in plant disease and defense: more than just jasmonate-salicylate antagonism. Annu. Rev. Phytopathol. 49, 317-343. doi: 10.1146/annurev-phyto-073009-114447

Ronald, P. C., Albano, B., Tabien, R., Abenes, L., Wu, K. S., McCouch, S., et al. (1992). Genetic and physical analysis of the rice bacterial blight disease resistance locus, Xa21. Mol. Gen. Genet. 236, 113-120. doi: 10.1007/BF00279649

Salmeron, J. M., Oldroyd, G. E. D., Rommens, C. M. T., Scofield, S. R., Kim, H.-S., Lavelle, D. T., et al. (1996). Tomato Prf is a member of the leucine-rich repeat class of plant disease resistance genes and lies embedded within the Pto kinase gene cluster. Cell 86, 123-133. doi: 10.1016/S0092-8674(00)80083-5

Sarrion-Perdigones, A., Vazquez-Vilar, M., Palací, J., Castelijns, B., Forment, J., Ziarsolo, P., et al. (2013). GoldenBraid 2.0: a comprehensive DNA assembly framework for plant synthetic biology. Plant Physiol. 162, 1618-1631. doi: 10.1104/pp.113.217661

Schornack, S., Moscou, M. J., Ward, E. R., and Horvath, D. M. (2013). Engineering plant disease resistance based on TAL effectors. Annu. Rev. Phytopathol. 51, 383 406. doi: 10.1146/annurev-phyto-082712-102255

Schulze-Lefert, P., and Panstruga, R. (2011). A molecular evolutionary concept connecting nonhost resistance, pathogen host range, and pathogen speciation. Trends Plant Sci. 16, 117-125. doi: 10.1016/j.tplants.2011.01.001

Scofield, S., Tobias, C., Rathjen, J., Chang, J., Lavelle, D., Michelmore, R., et al. (1996). Molecular basis of gene-for-gene specificity in bacterial speck disease of tomato. Science 274, 2063-2065. doi: 10.1126/science.274.5295.2063

Seifers, D. L., Haber, S., Martin, T. J., and McCallum, B. D. (2014). Heritable, de novo resistance to leaf rust and other novel traits in selfed descendants of wheat responding to inoculation with wheat streak mosaic virus. PLoS ONE 9:e86307. doi: 10.1371/journal.pone.0086307

Selote, D., and Kachroo, A. (2010). RIN4-like proteins mediate resistance proteinderived soybean defense against Pseudomonas syringae. Plant Signal. Behav. 5 1453-1456. doi: 10.1104/pp.110.158147

Sijmons, P. C., Grundler, F. M., Mende, N., Burrows, P. R., and Wyss, U. (1991). Arabidopsis thaliana as a new model host for plant-parasitic nematodes. Plant J. 1, 245-254. doi: 10.1111/j.1365-313X.1991.00245.x

Singh, A. K., Sharma, V., Pal, A. K., Acharya, V., and Ahuja, P. S. (2013). Genome-wide organization and expression profiling of the NAC transcription factor family in potato (Solanum tuberosum L.). DNA Res. 20, 403-423. doi: 10.1093/dnares/dst019

Slaughter, A., Daniel, X., Flors, V., Luna, E., Hohn, B., and Mauch-Mani, B. (2012). Descendants of primed Arabidopsis plants exhibit resistance to biotic stress. Plant Physiol. 158, 835-843. doi: 10.1104/pp.111.191593
Somerville, C., and Koornneef, M. (2002). A fortunate choice: the history of Arabidopsis as a model plant. Nat. Rev. Genet. 3, 883-889. doi: 10.1038/nrg927

Sprague, S. J., Balesdent, M.-H., Brun, H., Hayden, H. L., Marcroft, S. J., Pinochet, X., et al. (2006). Major gene resistance in Brassica napus (oilseed rape) is overcome by changes in virulence of populations of Leptosphaeria maculans in France and Australia. Eur. J. Plant Pathol. 114, 33-40. doi: 10.1007/s10658-0053683-5

Staal, J., Kaliff, M., Bohman, S., and Dixelius, C. (2006). Transgressive segregation reveals two Arabidopsis TIR-NB-LRR resistance genes effective against Leptosphaeria maculans, causal agent of blackleg disease. Plant J. 46, 218-230. doi: 10.1111/j.1365-313X.2006.02688.x

Staskawicz, B. J., Dahlbeck, D., and Keen, N. T. (1984). Cloned avirulence gene of Pseudomonas syringae pv. glycinea determines race-specific incompatibility on Glycine max (L.) Merr. Proc. Natl. Acad. Sci. U.S.A. 81, 6024-6028. doi: 10.1073/pnas.81.19.6024

Stein, M., Dittgen, J., Sánchez-Rodríguez, C., Hou, B. H., Molina, A., SchulzeLefert, P., et al. (2006). Arabidopsis PEN3/PDR8, an ATP binding cassette transporter, contributes to nonhost resistance to inappropriate pathogens that enter by direct penetration. Plant Cell 18, 731-746. doi: 10.1105/tpc.105. 038372

Takahashi, H., Shimizu, A., Arie, T., Rosmalawati, S., Fukushima, S., Kikuchi, M., et al. (2005). Catalog of Micro-Tom tomato responses to common fungal, bacterial, and viral pathogens. J. Gen. Plant Pathol. 71, 8-22. doi: 10.1007/s10327004-0168-x

Tang, P., Zhang, Y., Sunc, X., Tian, D., Yang, S., and Ding, J. (2010). Disease resistance signature of the leucine-rich repeat receptor-like kinase genes in four plant species. Plant Sci. 179, 399-406. doi: 10.1016/j.plantsci.2010. 06.017

Tang, X., Frederick, R., Zhou, J., Halterman, D., Jia, Y., and Martin, G. (1996). Initiation of plant disease resistance by physical interaction of AvrPto and Pto kinase. Science 274, 2060-2063. doi: 10.1126/science.274.5295.2060

Thilmony, R., Underwood, W., and He, S. Y. (2006). Genome-wide transcriptional analysis of the Arabidopsis thaliana interaction with the plant pathogen Pseudomonas syringae pv. tomato DC3000 and the human pathogen Escherichia coli O157:H7. Plant J. 46, 34-53. doi: 10.1111/j.1365-313X.2006. 02725.x

Thines, M., Choi, Y.-J., Kemen, E., Ploch, S., Holub, E. B., Shin, H.-D., et al. (2009). A new species of Albugo parasitic to Arabidopsis thaliana reveals new evolutionary patterns in white blister rusts (Albuginaceae). Persoonia 22, 123-128. doi: 10.3767/003158509X457931

Tian, D., Traw, M. B., Chen, J. Q., Kreitman, M., and Bergelson, J. (2003). Fitness costs of R-gene-mediated resistance in Arabidopsis thaliana. Nature 423, 74-77. doi: $10.1038 /$ nature 01588

Tomato Genome Consortium. (2012). The tomato genome sequence provides insights into fleshy fruit evolution. Nature 485, 635-641. doi: $10.1038 /$ nature 11119

Tripathi, J. N., Lorenzen, J., Bahar, O., Ronald, P., and Tripathi, L. (2014). Transgenic expression of the rice Xa21 pattern-recognition receptor in banana (Musa sp.) confers resistance to Xanthomonas campestris pv. musacearum. Plant Biotechnol. J. 12, 663-673. doi: 10.1111/pbi.12170

Tsuji, J. (1992). First report of natural infection of Arabidopsis thaliana by Xanthomonas campestris pv. campestris. Plant Dis. 76, 539. doi: 10.1094/PD76-0539A

Valls, M., Genin, S., and Boucher, C. (2006). Integrated regulation of the type III secretion system and other virulence determinants in Ralstonia solanacearum. PLoS Pathog. 2:e82. doi: 10.1371/journal.ppat.0020082

Van Der Biezen, E. A., and Jones, J. D. (1998). Plant disease-resistance proteins and the gene-for-gene concept. Trends Biochem. Sci. 23, 454-456. doi: 10.1016/S09680004(98)01311-5

van der Hoorn, R. A. L., and Kamoun, S. (2008). From guard to decoy: a new model for perception of plant pathogen effectors. Plant Cell 20, 2009-2017. doi: $10.1105 /$ tpc. 108.060194

Verma, P. R., Harding, H., Petrie, G. A., and Williams, P. H. (1975). Infection and temporal development of mycelium of Albugo candida in cotyledons of four Brassica species. Can. J. Bot. 53, 1016-1020. doi: 10.1139/b75-119

Walawage, S. L., Britton, M. T., Leslie, C. A., and Uratsu, S. L. (2013). Stacking resistance to crown gall and nematodes in walnut rootstocks. BMC Genomics 14:668. doi: 10.1186/1471-2164-14-668 
Walters, D. R., and Paterson, L. (2012). Parents lend a helping hand to their offspring in plant defence. Biol. Lett. 8, 871-873. doi: 10.1098/rsbl.2012.0416

Wang, X., Basnayake, B. M. V. S., Zhang, H., Li, G., Li, W., Virk, N., et al. (2009). The Arabidopsis ATAF1, a NAC transcription factor, is a negative regulator of defense responses against necrotrophic fungal and bacterial pathogens. Mol. Plant Microbe Interact. 22, 1227-1238. doi: 10.1094/MPMI-22-10-1227

Wang, Y., Cheng, X., Shan, Q., Zhang, Y., Liu, J., Gao, C., et al. (2014). Simultaneous editing of three homoeoalleles in hexaploid bread wheat confers heritable resistance to powdery mildew. Nat. Biotechnol. 32, 947-951. doi: 10.1038/nbt.2969

Weßling, R., Epple, P., Altmann, S., He, Y., Yang, L., Henz, S. R., et al. (2014). Convergent targeting of a common host protein-network by pathogen effectors from three kingdoms of life. Cell Host Microbe 16, 364-375. doi: 10.1016/j.chom.2014.08.004

Whalen, M. C., Innes, R. W., Bent, A. F., and Staskawicz, B. J. (1991). Identification of Pseudomonas syringae pathogens of Arabidopsis and a bacterial locus determining avirulence on both Arabidopsis and soybean. Plant Cell 3, 49-59. doi: 10.1105/tpc.3.1.49

Whitham, S., Dinesh-Kumar, S. P., Choi, D., Hehl, R., Corr, C., and Baker, B. (1994). The product of the tobacco mosaic virus resistance gene N: similarity to toll and the interleukin-1 receptor. Cell 78, 1101-1115. doi: 10.1016/00928674(94)90283-6

Williams, S. J., Sohn, K. H., Wan, L., Bernoux, M., Sarris, P. F., Segonzac, C., et al. (2014). Structural basis for assembly and function of a heterodimeric plant immune receptor. Science 344, 299-303. doi: 10.1126/science.1247357

Windram, O., Madhou, P., McHattie, S., Hill, C., Hickman, R., Cooke, E., et al. (2012). Arabidopsis defense against Botrytis cinerea: chronology and regulation deciphered by high-resolution temporal transcriptomic analysis. Plant Cell 24 3530-3557. doi: 10.1105/tpc.112.102046

Windram, O., Penfold, C. A., and Denby, K. J. (2014). Network modeling to understand plant immunity. Annu. Rev. Phytopathol. 52, 93-111. doi 10.1146/annurev-phyto-102313-050103

Winter, D., Vinegar, B., Nahal, H., Ammar, R., Wilson, G. V., and Provart, N. J. (2007). An "Electronic Fluorescent Pictograph" browser for exploring and analyzing largescale biological data sets. PLoS ONE 2:e718. doi: 10.1371/journal.pone.0000718

Xie, D. X., Feys, B. F., James, S., Nieto-Rostro, M., and Turner, J. G. (1998). COI1: an Arabidopsis gene required for jasmonate-regulated defense and fertility. Science 280, 1091-1094. doi: 10.1126/science.280.5366.1091

Xin, X.-F., and He, S. Y. (2013). Pseudomonas syringae pv. tomato DC3000: a model pathogen for probing disease susceptibility and hormone signaling in plants. Annu. Rev. Phytopathol. 51, 473-498. doi: 10.1146/annurev-phyto-082712102321

Xing, W., Zou, Y., Liu, Q., Liu, J., Luo, X., Huang, Q., et al. (2007). The structural basis for activation of plant immunity by bacterial effector protein AvrPto. Nature 449, 243-247. doi: 10.1038/nature06109

Xu, M.-R., Huang, L.-Y., Zhang, F., Zhu, L.-H., Zhou, Y.-L., and Li, Z.-K. (2013) Genome-wide phylogenetic analysis of stress-activated protein kinase genes in rice (OsSAPKs) and expression profiling in response to Xanthomonas oryzae pv. oryzicola infection. Plant Mol. Biol. Rep. 31, 877-885. doi: 10.1007/s11105-0130559-2
Yang, S., Li, J., Zhang, X., Zhang, Q., Huang, J., Chen, J.-Q., et al. (2013a) Rapidly evolving $\mathrm{R}$ genes in diverse grass species confer resistance to rice blast disease. Proc. Natl. Acad. Sci. U.S.A. 110, 18572-18577. doi: 10.1073/pnas.13182 11110

Yang, Y., Jittayasothorn, Y., Chronis, D., Wang, X., Cousins, P., and Zhong, G.-Y. (2013b). Molecular characteristics and efficacy of 16D10 siRNAs in inhibiting root-knot nematode infection in transgenic grape hairy roots. PLoS ONE 8:e69463. doi: 10.1371/journal.pone.0069463

Yoshida, R., Hobo, T., Ichimura, K., Mizoguchi, T., Takahashi, F., Aronso, J., et al. (2002). ABA-activated SnRK2 protein kinase is required for dehydration stress signaling in Arabidopsis. Plant Cell Physiol. 43, 1473-1483. doi: $10.1093 / \mathrm{pcp} / \mathrm{pcf} 188$

Zhang, J., Li, W., Xiang, T., Liu, Z., Laluk, K., Ding, X., et al. (2010). Receptor-like cytoplasmic kinases integrate signaling from multiple plant immune receptors and are targeted by a Pseudomonas syringae effector. Cell Host Microbe 7, 290-301. doi: 10.1016/j.chom.2010.03.007

Zhao, B., Ardales, E. Y., Raymundo, A., Bai, J., Trick, H. N., Leach, J. E., et al. (2004). The avrRxol gene from the rice pathogen Xanthomonas oryzae pv. oryzicola confers a nonhost defense reaction on maize with resistance gene Rxo1. Mol. Plant Microbe Interact. 17, 771-779. doi: 10.1094/MPMI.2004.17. 7.771

Zhao, B., Lin, X., Poland, J., Trick, H., Leach, J., and Hulbert, S. (2005). A maize resistance gene functions against bacterial streak disease in rice. Proc. Natl. Acad. Sci. U.S.A. 102, 15383-15388. doi: 10.1073/pnas.05030 23102

Zhu, Z., Xu, F., Zhang, Y., Cheng, Y. T., Wiermer, M., Li, X., et al. (2010). Arabidopsis resistance protein $\mathrm{SNC1}$ activates immune responses through association with a transcriptional corepressor. Proc. Natl. Acad. Sci. U.S.A. 107, 13960-13965. doi: 10.1073/pnas.1002828107

Zimmermann, P., Hirsch-Hoffmann, M., Hennig, L., and Gruissem, W. (2004). GENEVESTIGATOR. Arabidopsis microarray database and analysis toolbox. Plant Physiol. 136, 2621-2632. doi: 10.1104/pp.104.046367

Conflict of Interest Statement: The authors declare that the research was conducted in the absence of any commercial or financial relationships that could be construed as a potential conflict of interest.

Received: 15 September 2014; accepted: 10 November 2014; published online: 03 December 2014.

Citation: Piquerez SJM, Harvey SE, Beynon JL and Ntoukakis V (2014) Improving crop disease resistance: lessons from research on Arabidopsis and tomato. Front. Plant Sci. 5:671. doi: 10.3389/fpls.2014.00671

This article was submitted to Plant-Microbe Interaction, a section of the journal Frontiers in Plant Science.

Copyright $(2014$ Piquerez, Harvey, Beynon and Ntoukakis. This is an open-access article distributed under the terms of the Creative Commons Attribution License (CC BY). The use, distribution or reproduction in other forums is permitted, provided the original author(s) or licensor are credited and that the original publication in this journal is cited, in accordance with accepted academic practice. No use, distribution or reproduction is permitted which does not comply with these terms. 